\title{
MILITARIA Z OKOLÍ HRADU RYCHMBERKA VE VÝCHODNÍCH ČECHÁCH JAKO DOKLADY JEHO DOBÝVÁNÍ
}

\author{
PAVEL DRNOVSKÝ - TOMÁŠ BEK - MARTINA BEKOVÁ
}

\begin{abstract}
Abstrakt: Studie se věnuje vyhodnocení nálezového souboru militarii z hradu Rychmberka u Rychnova nad Kněžnou. Nálezy pocházi z detektorového průzkumu a disponujeme jejich prostorovými daty. Kolekce je tvořena zejména hroty šípů a projektily palných zbraní. Na základě prostorové distribuce artefaktů je možno odlišit munici obráncủ a obléhatelů, stejnè tak lze interpretovat směry útoků na hrad. Vzhledem k charakteru souboru a nižší chronologické citlivosti militarií však nelze nálezy roztřídit a přiřadit ke konkrétní historické události. Z pisemných pramenů je doloženo obléhání hradu v letech 1425, 1441 a 1457.
\end{abstract}

Kličová slova: hrad - militaria - kovové nálezy - dobývání-archeologie vojenství-východní Čechy.

\section{Militaria from the vicinity of Rychmberk Castle, eastern Bohemia as the evidence of its besieging}

\begin{abstract}
This study is dedicated to the assessment of a series of finds from Rychmberk Castle, near Rychnov nad Kněžnou. The finds come from metal detector prospecting and include spatial data. The series largely consists of arrow tips and shots from firearms. Based on the spatial distribution of the objects it is possible to distinguish between the ammunition of the defenders and that of the besiegers; the directions of the attacks can be interpreted as well. However, owing to the character of the series and the relatively low chronological sensitivity of militaria, the finds cannot be sorted out and linked to particular historical events. Written sources document sieges of the castle in 1425, 1441 and 1457.
\end{abstract}

Key words: castle - militaria - metal finds - siege - military archaeology-eastern Bohemia.

\section{1 Úvod}

Oblasti nacházející se $\mathrm{v}$ podhůří Orlických hor byly na počátku husitských válek převážně v držení pánů, kteří patřili do tábora krále Zikmunda Lucemburského (Šandera 2005). Z tohoto důvodu zde východočeští husité v polovině 20 . let 15 . století podnikli sérii vojenských výprav, během nichž proběhlo úspěšné obležení a dobytí několika opevněných sídel. Stejně jako v jiných částech Čech ani v Podorlicku s ukončením husitských válek nepokoje neustaly. Zdejší kraj byl svědkem bojů, ve kterých sehrával úlohu Jan Kolda ze Žampachu (Wolf 2002). Hrad Rychmberk, někdy v literatuře mylně uváděný pod současným názvem obce Liberk, $\mathrm{v}$ jehož katastrálním území se lokalita nachází, byl během těchto střetů celkem třikrát obležen a minimálně dvakrát dobyt. Cílem studie je vyhodnotit objemný nálezový soubor militarií pocházející z tohoto hradu a jeho okolí. Na rozdíl od podobných kolekcí vzešlých z detektorového průzkumu byly při této prospekci organizované rychnovským muzeem zaznamenávány prostorové údaje jednotlivých artefaktů, díky čemuž je možno rozvinout interpretační rámec souboru.

\section{Umístění lokality, její historie a stručný popis}

Pozůstatky hradu Rychmberka se nachází na západním okraji obce Liberk nedaleko Rychnova nad Kněžnou (obr. 1). Stavebník si pro sídlo vybral úzký skalnatý ostroh, který je vymezen prudkými údolími Liberského potoka ze severu a bezejmenné vodoteče z jihu (obr. 2). Vzhledem k blízkosti Rychnova se historické bádání shoduje na souvislosti vzniku hradu s kolonizačním úsilím šlechtického rodu pánů z Drnholce (Musil-Svoboda 1998, 138; Plaček 1991, 146; Šimek a kol. 1989, 426). Př́íslušníci tohoto původem moravského rodu prováděli v druhé polovině 13 . století zejména kolonizaci v povodí Tiché Orlice a rovněž na řece Kněžné (Musil 2009, 352-353). Př́ídomek z Rychmberka (Richenberch) prvně užívá v roce 1310 Vilém, jenž by snad mohl být i jeho zakladatelem (RBM II, 967 č. 2230). V roce 1318 jsou pak zmíněni jako držitelé Držislav, Heřman, 


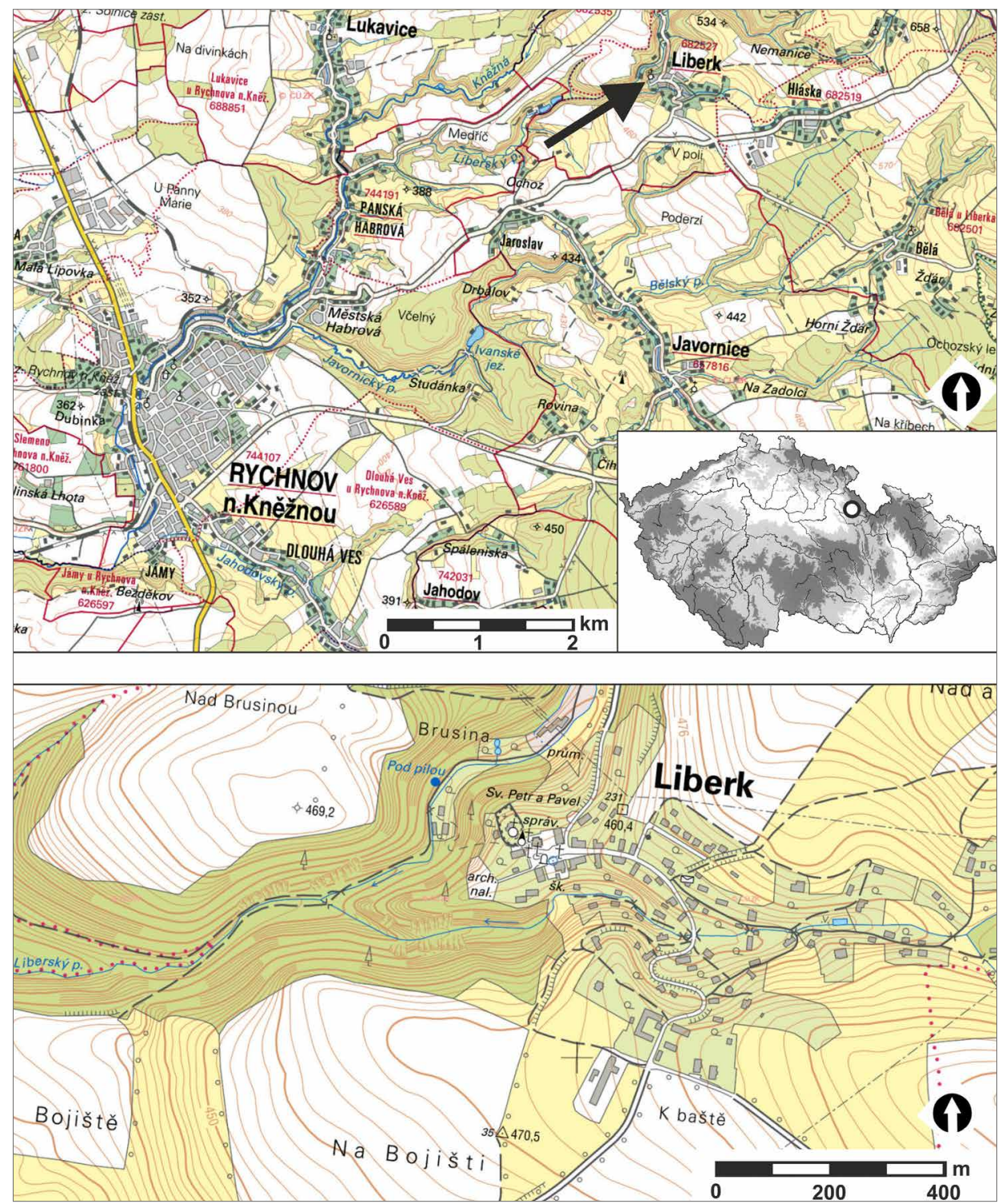

Obr. 1. Poloha Liberku vůči Rychnovu nad Kněžnou a základní polohopis okolí lokality.

Abb. 1. Lage von Liberk gegenüber Rychnov nad Kněžnou und Grundlageplan der Fundstättenumgebung.

Oldřich, Jeruše a Ješek (RT I, 25, 81), kteří byli pohnáni před soud kvůli přepadení okolních sídel v Pěčíně a Rokytnici. V držení pánů z Rychmberka je sídlo naposledy zmíněno v roce 1355 , kdy Dobeš, Heřman a Oldřich dosazují faráře v Nebeské Rybné (LC I/1, 23). Již v roce 1367 totiž drží patronátní právo ke kostelu v Rychmberku bratři Jan a Vznata ze Skuhrova, tedy majitelé blízkého hradu ve Skuhrově nad Bělou (LC I/2, 90). V roce 1387 se hrad dostává do rukou Půtovi (I.) staršímu z Častolovic. Jako držitel je též zmíněn i Boček z Kunštátu (Sedláček 1883, 190). Půta pak hrady Rychmberk a Skuhrov zapisuje v roce 1396 Anně Osvětimské, manželce svého syna Půty (II.) mladšího z Častolovic. Tehdy je prvně výslovně uveden i hrad (AČ 2, 49 č. 2). Anna 


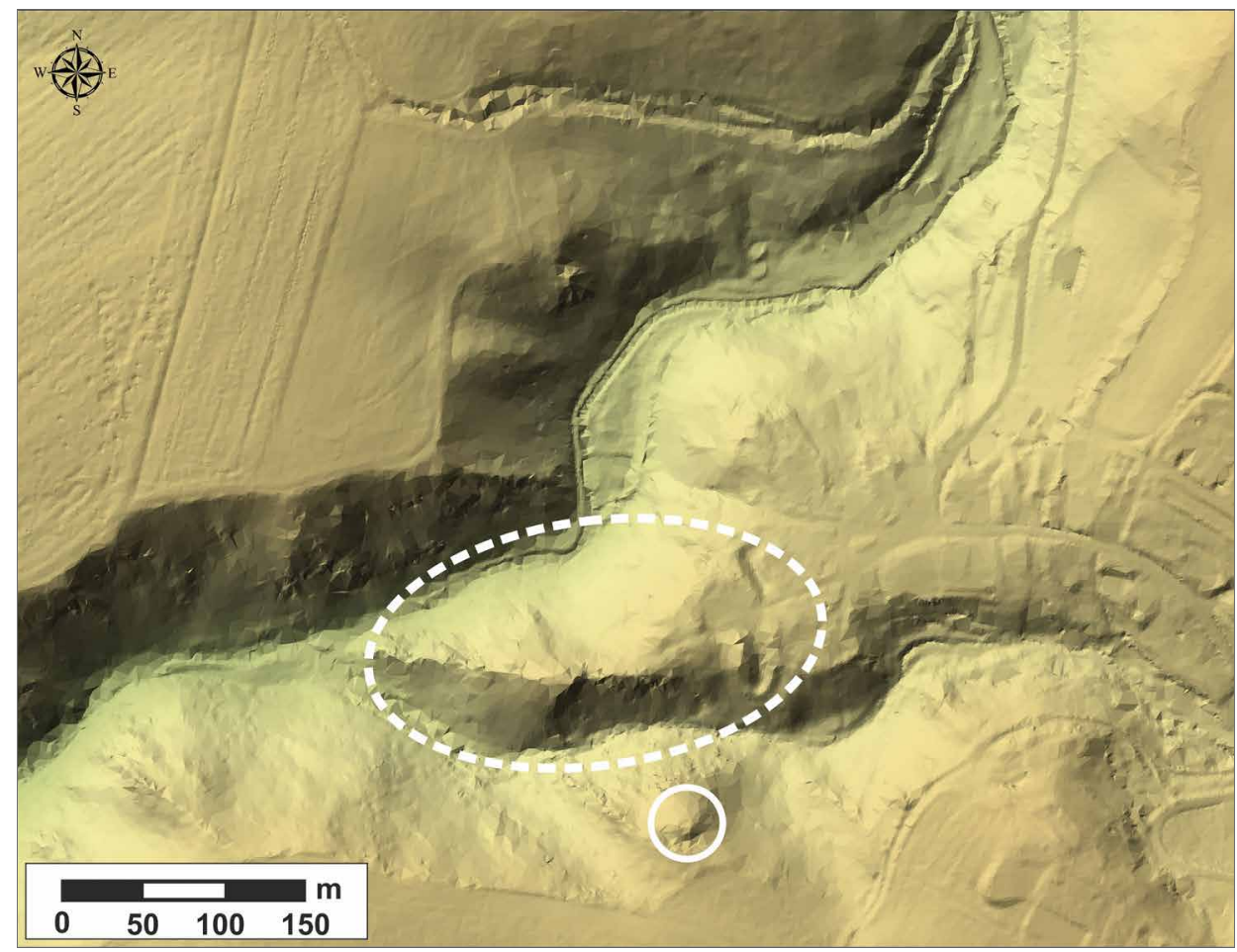

Obr. 2. Hrad Rychmberk. Terénní model reliéfu. Hradní ostrožna a areál hradu ohraničen bílou elipsou. Bílým kruhem je označena poloha fortifikace na protilehlém jižním svahu. Na základě podkladů P. Drnovského vytvořil M. Lanta.

Abb. 2. Burg Rychmberk. Geländereliefmodell. Burgfelssporn und Burgareal mit weißer Ellipse umgrenzt. Mit weißem Kreis gekennzeichnet ist die Lage der Befestigungsanlage am gegenüberliegenden Südhang. Nach P. Drnovskýs Unterlagen erstellt von M. Lanta.

Osvětimská Rychmberk užívala jako své sídlo, a to i po smrti manžela, kdy se stala poručnicí svého syna Půty (III.) nejmladšího z Častolovic. Jemu pak v roce 1415 sice nechala zapsat své statky, avšak s vymíněním jejich užívání až do své smrti (Sedláček 1883, 191). Půta III. patřil během husitských válek ke spojencům Zikmunda Lucemburského a byl i jednou z hlavních postav tzv. opočenské strany (Šandera 2005). Z tohoto důvodu byl hrad v roce 1425 obležen a dobyt východočeskými husity pod velením Jana Hvězdy z Vícemilic (Musil-Svoboda 1998, 139; Sedláček 1883, 191). Jak moc byl hrad poničen a zda byl nadále obýván a držen husity, nevíme. Přes jeho dobytí husity v roce 1432 dosazuje Anna Osvětimská katolického duchovního do fary v Rychmberku (Kurka 1914, 580). Po smrti Půty III. (1435) se hradu zmocnil Jan Kolda mladší ze Žampachu. V roce 1441 byla proti němu vedena vojenská kampaň pod vedením královéhradeckého hejtmana Jetřicha z Miletínka. Hotovost hradeckého, kouřimského a čáslavského kraje v tomto roce nejprve dobyla v červnu 1441 jiná Koldova sídla Dubenec a Černíkovice. Posléze oblehla i Rychmberk a hrad v Náchodě (Musil-Svoboda 1998, 139). K vojenské akci se kromě krajských sil připojilo i slezské vojsko, zmíněna je i přítomnost tří větších pušek (Sedláček 1883, 191; Šandera 2009, 590; Wolf 2002, 41). Jan Kolda v této fázi musel přistoupit na smírnou dohodu, načež si mohl ponechat Náchod a patrně i Rychmberk. Po smrti Anny Osvětimské (1454) se o rychmberské panství přihlásil jako o odúmrt' král Jiří z Poděbrad (Musil-Svoboda 1998, 139). Jiř́i z Poděbrad rovněž těžil ze skutečnosti, že jako spolumajitel panství byl v roce 1387 uváděn jeho předek Boček z Kunštátu (Sedláček 1883, 191). Vzhledem k nastalému nepřátelství Jana Koldy a krále Jiřího byl hrad opět v dubnu 1457 obležen a dobyt (Wolf 2002, 53-64). Panství rychmberské 
bylo následně přičleněno k litickému zboží a sám hrad byl patrně pobořen (Musil-Svoboda 1998, 140). Po smrti krále získává panství litické a zboží rychmberské jeho syn Boček (AČ 1, 302). Posléze se pak tyto državy dostávají do držení jeho bratra Jindřicha Minsterberského, který je však musí v roce 1495 prodat Vilémovi z Pernštejna. Tehdy je hrad Rychmberk prvně zmíněn jako pustý $(A C ̌$ 5, 550). Samo městečko Rychmberk s dalším vývojem přišlo o svá práva a stalo se vsí. Postupem času se původní jméno Rychmberk změnilo komolením na Richberk, Riberk a dále na Liberk, kteréžto toponymum se používá dodnes (Profous 1949, 584). Pod tímto názvem pak bývá hrad někdy nepřesně označován $\mathrm{v}$ dnešní době.

Jak již bylo uvedeno, hrad stával na výrazném ostrohu, který byl přirozeně chráněn strmými srázy ze tř́ stran (obr. 2). Přístup ke hradu vedl od východu, přes podhradní městečko. Vzhledem $\mathrm{k}$ absenci přirozených překážek zde byla šíje ostrohu přet'ata trojící př́ikopů. Vytěžený materiál pak posloužil k navršení dvojice valů, které se nacházely mezi zmíněnými př́ikopy. Za touto fortifikací se nacházelo předhradí, jehož délka dosahovala přibližně 80 metrů (obr. 3). Tvar předhradí byl určen postupně se zužujícím ostrohem a má tak trychtýřovitý půdorys. Samotné jádro bylo odděleno vylámaným př́kopem do skály. Stále více zužující se plošina umožnila stavebníkovi hradu využít prostor pouze zhruba 25 na 14 metrů. Využita nejspíše byla i níže položená opyš západně od tohoto jádra a patrně i jižně umístěná podélná plošina, snad prostor parkánu. Ze stavby hradu se do dnešní doby nedochovaly nadzemní zděné konstrukce, jakýkoliv bližší popis podoby hradu je tak nemožný. Vzhledem k omezenému prostoru hradního jádra však můžeme očekávat spíše jednu blokovou palácovou stavbu. Dvě nevelké konkávní jámy v jádru hradu by snad mohly být pozůstatky suterénu či podsklepených prostor této stavby (Musil-Svoboda 1998, 140; Plaček 1991, 146).

Během terénní prospekce prováděné v roce 2016 byly objeveny na jižním protilehlém svahu zbytky drobné fortifikace vymezené ze tří stran př́íkopem (obr. 2). Vnitřní plocha tohoto útvaru zabírá prostor přibližně $15 \times 20 \mathrm{~m}$. Autoři výzkumu považují tento útvar za předsunuté opevnění zlepšující obranyschopnost hradu (Beková-Slavík 2021, 264-265). Dle našeho názoru však nelze opomenout ani možnost zbudování této fortifikace útočníky během jednoho z obléhání. Objekt by pak mohl sloužit jakožto střelecké postavení dobyvatelů.

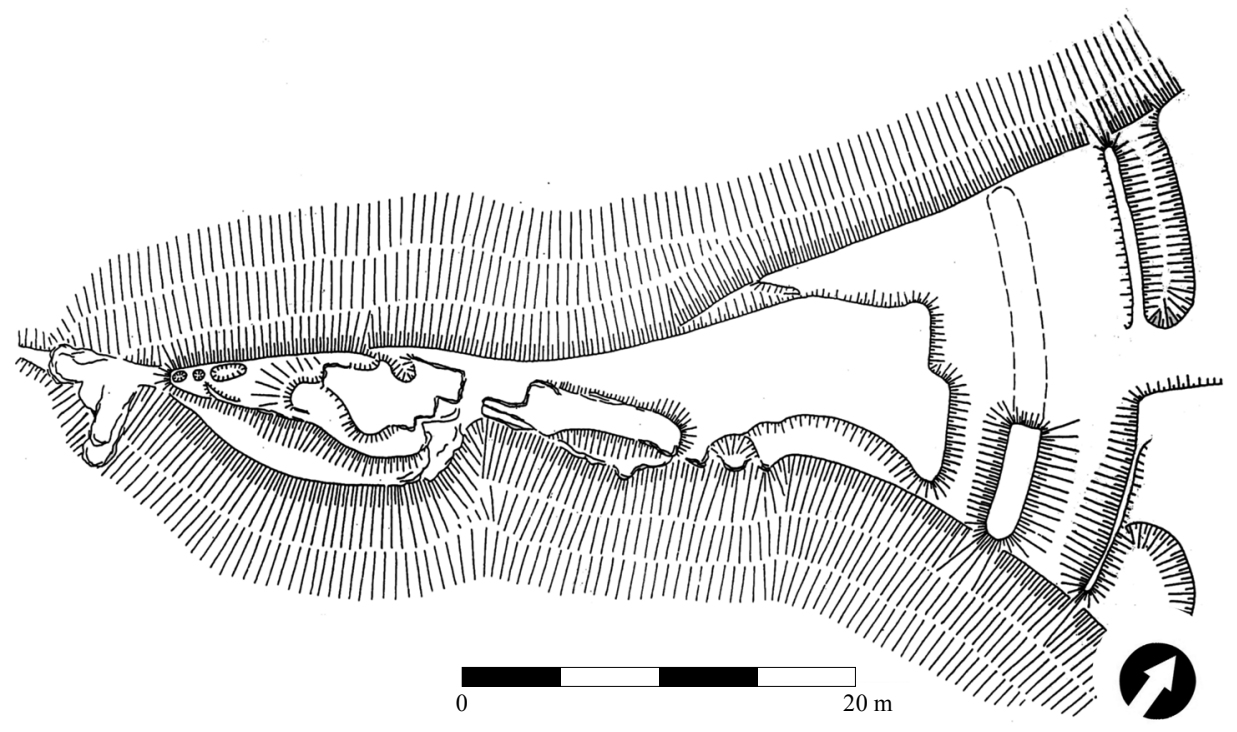

Obr. 3. Hrad Rychmberk. Půdorys hradu podle M. Plačka (1991, 147, obr. 1). Upravil P. Drnovský.

Abb. 3. Burg Rychmberk. Grundriss der Burg nach M. Plaček (1991, 147, Abb. 1). Bearbeitung von P. Drnovský. 


\section{Rozbor nálezů}

\subsection{Nálezové okolnosti souboru}

Vzhledem k tomu, že relikty hradu Rychmberka a jeho okolí byly opakovaně postihovány nelegálním průzkumem detektory kovů, přistoupilo archeologické oddělení Muzea a galerie Orlických hor v Rychnově nad Kněžnou k realizaci cíleného detektorového průzkumu, který proběhl v několika akcích během let 2013-2015. ${ }^{1}$ Výzkum byl veden PhDr. Martinou Bekovou. Samotná prospekce byla $\mathrm{v}$ terénu odborně řízena Bc. Tomášem Bekem. V rozmezí uvedených roků byly postupně sbírány artefakty $\mathrm{z}$ jednotlivých ploch v areálu hradu a jeho okolí. Sběrů se účastnili tři až čtyřri dobrovolní spolupracovníci. ${ }^{2}$ Každý z nálezů byl zaměřen pomocí ruční GPS, zpravidla byla zaznamenána hloubka jeho uložení a u vybraných hrotů šípů i jejich směřování. Azimut uložení hrotů šípů nebyl sledován, pouze u vybraných hrotů bylo zaznamenáno uložení vzhledem k hradu (od něj nebo k němu). Soubor je velmi obsáhlý, a proto je $\mathrm{v}$ této studii věnována pozornost pouze nálezům, jež lze zařadit mezi militaria (tab. 1). Pro přehlednost byly jednotlivým artefaktům přidělena katalogová čísla, se kterými text dále pracuje, nálezy jsou pod nimi uvedeny i v mapových a obrazových př́lohách.

Tab. 1. Základní dělení militarií.

Tab. 1. Grundeinteilung der Militaria.

\begin{tabular}{|l|c|}
\hline hrot šípu & 188 \\
\hline projektil & 76 \\
\hline samostříl & 2 \\
\hline tesák & 2 \\
\hline ostruha & 1 \\
\hline Součet & 269 \\
\hline
\end{tabular}

\subsection{Hroty šípio}

Nejpočetněji zastoupenou skupinu militarií představují hroty šípů. Celkem se jedná o 188 jedinců (tab. 2). Během zpracování byly sledovány jejich metrické a morfologické vlastnosti. Pro jejich trrídění se přidržíme standardně použivaných typologií. Při výčtu analogií pak budou uváděny zejména chronologicky přesněji vymezené soubory. Do statistických výpočtů váhy a délky byly zahrnuty pouze kompletní jedinci, nikoliv torza hrotů.

Tab. 2. Hroty šípů. Metrické a nálezové vlastnosti.

Tab. 2. Pfeilspitzen. Metrische und Fundeigenschaften.

\begin{tabular}{|c|c|c|c|c|c|}
\hline číslo nálezu & délka (mm) & váha $(\mathrm{g})$ & hloubka $(\mathrm{cm})$ & ev. číslo & JTSK \\
\hline 7 & 90 & 45,48 & 10 & A 346 & $X-605316 m, Y-1047773 m$ \\
\hline 8 & 75 & 43,08 & 40 & A347 & $X-605317 \mathrm{~m}, \mathrm{Y}-1047753 \mathrm{~m}$ \\
\hline 9 & 88 & 51,86 & & A348 & $X-605753 m, Y-1049679 m$ \\
\hline 10 & 62 & 17,9 & 12 & A349 & $X-605326 \mathrm{~m}, \mathrm{Y}-1047749 \mathrm{~m}$ \\
\hline 11 & 76 & 29,65 & 18 & A 350 & $X-605322 \mathrm{~m}, \mathrm{Y}-1047768 \mathrm{~m}$ \\
\hline 12 & 61 & 11,68 & & A351 & $X-605351 \mathrm{~m}, \mathrm{Y}-1047849 \mathrm{~m}$ \\
\hline 13 & 53 & 16,61 & & A354 & $\mathrm{X}-604969 \mathrm{~m}, \mathrm{Y}-1047660 \mathrm{~m}$ \\
\hline 14 & 74 & 15,04 & 3 & A 355 & $X-605300 \mathrm{~m}, \mathrm{Y}-1047764 \mathrm{~m}$ \\
\hline
\end{tabular}

1 Nálezy zpracované v této studii jsou uloženy v Muzeu a galerii Orlických hor v Rychnově nad Kněžnou.

2 Jmenovitě lze uvést pány M. Komárka, M. Malého a R. Skácela. 


\begin{tabular}{|c|c|c|c|c|c|}
\hline 15 & 80 & 41,07 & 15 & A356 & $\mathrm{X}-605321 \mathrm{~m}, \mathrm{Y}-1047762 \mathrm{~m}$ \\
\hline 18 & 65 & 16,36 & 18 & A344 & $X-605314 m, Y-1047786 m$ \\
\hline 22 & 79 & 42,36 & 12 & A343 & $\mathrm{X}-605320 \mathrm{~m}, \mathrm{Y}-1047769 \mathrm{~m}$ \\
\hline 24 & 120 & 42,67 & 17 & A 342 & $\mathrm{X}-605323 \mathrm{~m}, \mathrm{Y}-1047783 \mathrm{~m}$ \\
\hline 28 & 105 & 48,51 & & A376 & $\mathrm{X}-605311 \mathrm{~m}, \mathrm{Y}-1047708 \mathrm{~m}$ \\
\hline 29 & 109 & 39,99 & & A377 & $X-605276 \mathrm{~m}, \mathrm{Y}-1047669 \mathrm{~m}$ \\
\hline 30 & 100 & 53,28 & & A378 & $\mathrm{X}-605321 \mathrm{~m}, \mathrm{Y}-1047870 \mathrm{~m}$ \\
\hline 31 & 105 & 42,11 & & A379 & $\mathrm{X}-605255 \mathrm{~m}, \mathrm{Y}-1047686 \mathrm{~m}$ \\
\hline 32 & 90 & 55,03 & & A 380 & $\mathrm{X}-605302 \mathrm{~m}, \mathrm{Y}-1047841 \mathrm{~m}$ \\
\hline 33 & 86 & 44,98 & & A381 & $X-605284 \mathrm{~m}, \mathrm{Y}-1047858 \mathrm{~m}$ \\
\hline 34 & 85 & 42,53 & & A382 & $\mathrm{X}-605280 \mathrm{~m}, \mathrm{Y}-1047681 \mathrm{~m}$ \\
\hline 35 & 80 & 44,86 & & A383 & $X-605413 m, Y-1047819 m$ \\
\hline 36 & 70 & 27,29 & & A384 & $X-605293 \mathrm{~m}, \mathrm{Y}-1047856 \mathrm{~m}$ \\
\hline 37 & 52 & 29,36 & & A385 & $\mathrm{X}-605301 \mathrm{~m}, \mathrm{Y}-1047704 \mathrm{~m}$ \\
\hline 38 & 80 & 36,47 & & A386 & $X-605308 m, Y-1047660 m$ \\
\hline 39 & 68 & 34,78 & & A387 & $X-605268 \mathrm{~m}, \mathrm{Y}-1047863 \mathrm{~m}$ \\
\hline 40 & 80 & 45,57 & & A 388 & - \\
\hline 41 & 90 & 47,55 & & A389 & $X-605307 m, Y-1047654 m$ \\
\hline 42 & 86 & 45,43 & & A 390 & $X-605305 \mathrm{~m}, \mathrm{Y}-1047854 \mathrm{~m}$ \\
\hline 43 & 105 & 51,42 & & A391 & $\mathrm{X}-605171 \mathrm{~m}, \mathrm{Y}-1047590 \mathrm{~m}$ \\
\hline 44 & 75 & 44,94 & 30 & A458 & $\mathrm{X}-605262 \mathrm{~m}, \mathrm{Y}-1047633 \mathrm{~m}$ \\
\hline 45 & 76 & 47,54 & 5 & A459 & $X-605239 m, Y-1047679 m$ \\
\hline 46 & 110 & 53,9 & 20 & A460 & $X-605241 \mathrm{~m}, \mathrm{Y}-1047679 \mathrm{~m}$ \\
\hline 47 & 72 & 32,55 & 12 & A461 & $X-605398 m, Y-1047793 m$ \\
\hline 48 & 77 & 30,89 & & A463 & $\mathrm{X}-605397 \mathrm{~m}, \mathrm{Y}-1047791 \mathrm{~m}$ \\
\hline 49 & 70 & 32,39 & 7 & A462 & $X-605414 \mathrm{~m}, \mathrm{Y}-1047783 \mathrm{~m}$ \\
\hline 50 & 85 & 31,76 & 10 & A464 & $\mathrm{X}-605299 \mathrm{~m}, \mathrm{Y}-1047732 \mathrm{~m}$ \\
\hline 51 & 85 & 19,43 & 30 & A465 & $X-605307 \mathrm{~m}, \mathrm{Y}-1047794 \mathrm{~m}$ \\
\hline 52 & 75 & 42,93 & 20 & A466 & $X-605280 \mathrm{~m}, \mathrm{Y}-1047710 \mathrm{~m}$ \\
\hline 53 & 60 & 35,23 & 60 & A467 & $\mathrm{X}-605300 \mathrm{~m}, \mathrm{Y}-1047727 \mathrm{~m}$ \\
\hline 54 & 118 & 56,6 & & A468 & $X-605289 \mathrm{~m}, \mathrm{Y}-1047698 \mathrm{~m}$ \\
\hline 55 & 87 & 21,49 & 22 & A469 & $X-605293 \mathrm{~m}, \mathrm{Y}-1047712 \mathrm{~m}$ \\
\hline 56 & 78 & 17,88 & 20 & A470 & $\mathrm{X}-605299 \mathrm{~m}, \mathrm{Y}-1047721 \mathrm{~m}$ \\
\hline 57 & 88 & 18,64 & 10 & A471 & $X-605403 \mathrm{~m}, \mathrm{Y}-1047803 \mathrm{~m}$ \\
\hline 58 & 80 & 35,72 & & A472 & $X-605342 \mathrm{~m}, \mathrm{Y}-1047656 \mathrm{~m}$ \\
\hline 59 & 72 & 38,72 & 15 & A473 & $\mathrm{X}-605273 \mathrm{~m}, \mathrm{Y}-1047642 \mathrm{~m}$ \\
\hline 60 & 85 & 43,65 & & A474 & - \\
\hline 61 & 73 & 14,36 & & A475 & $X-605397 \mathrm{~m}, \mathrm{Y}-1047791 \mathrm{~m}$ \\
\hline 63 & 76 & 38,3 & & A392 & $X-605349 \mathrm{~m}, \mathrm{Y}-1047716 \mathrm{~m}$ \\
\hline 64 & 70 & 35,39 & & A393 & $X-605158 \mathrm{~m}, \mathrm{Y}-1047599 \mathrm{~m}$ \\
\hline 65 & 95 & 49,49 & 20 & A441 & $\mathrm{X}-605261 \mathrm{~m}, \mathrm{Y}-1047664 \mathrm{~m}$ \\
\hline 66 & 63 & 28,69 & 14 & A442 & $\mathrm{X}-605350 \mathrm{~m}, \mathrm{Y}-1047825 \mathrm{~m}$ \\
\hline 67 & 80 & 56,83 & 30 & A443 & $\mathrm{X}-605343 \mathrm{~m}, \mathrm{Y}-1047816 \mathrm{~m}$ \\
\hline 68 & 100 & 45,47 & 15 & A444 & $X-605283 \mathrm{~m}, \mathrm{Y}-1047805 \mathrm{~m}$ \\
\hline 69 & 75 & 10,87 & 10 & A445 & $\mathrm{X}-605278 \mathrm{~m}, \mathrm{Y}-1047657 \mathrm{~m}$ \\
\hline
\end{tabular}




\begin{tabular}{|c|c|c|c|c|c|}
\hline 70 & 69 & 15,74 & 30 & A446 & $\mathrm{X}-605321 \mathrm{~m}, \mathrm{Y}-1047683 \mathrm{~m}$ \\
\hline 71 & 83 & 55,49 & 32 & A447 & $\mathrm{X}-605352 \mathrm{~m}, \mathrm{Y}-1047707 \mathrm{~m}$ \\
\hline 72 & 114 & 54,47 & 15 & A 448 & $X-605348 \mathrm{~m}, \mathrm{Y}-1047902 \mathrm{~m}$ \\
\hline 73 & 115 & 51,15 & 16 & A449 & $X-605340 \mathrm{~m}, \mathrm{Y}-1047822 \mathrm{~m}$ \\
\hline 74 & 105 & 57,57 & 23 & $\mathrm{~A} 450$ & $\mathrm{X}-605241 \mathrm{~m}, \mathrm{Y}-1047661 \mathrm{~m}$ \\
\hline 75 & 78 & 33,84 & 40 & A451 & $\mathrm{X}-605337 \mathrm{~m}, \mathrm{Y}-1047704 \mathrm{~m}$ \\
\hline 76 & 84 & 54,36 & 35 & A452 & - \\
\hline 77 & 112 & 34,03 & 30 & A453 & $\mathrm{X}-605287 \mathrm{~m}, \mathrm{Y}-1047643 \mathrm{~m}$ \\
\hline 78 & 75 & 34,05 & & A454 & $X-605243 \mathrm{~m}, \mathrm{Y}-1047679 \mathrm{~m}$ \\
\hline 79 & 90 & 48,14 & 25 & A455 & $\mathrm{X}-605312 \mathrm{~m}, \mathrm{Y}-1047635 \mathrm{~m}$ \\
\hline 80 & 74 & 48,68 & 13 & A456 & $X-605286 \mathrm{~m}, \mathrm{Y}-1047636 \mathrm{~m}$ \\
\hline 81 & 75 & 39,73 & 13 & A457 & $X-605262 \mathrm{~m}, \mathrm{Y}-1047633 \mathrm{~m}$ \\
\hline 82 & 84 & 36,6 & 10 & & $\mathrm{X}-605175 \mathrm{~m}, \mathrm{Y}-1047580 \mathrm{~m}$ \\
\hline 83 & 66 & 27,74 & 10 & & - \\
\hline 84 & 105 & 47,4 & 12 & & $\mathrm{X}-605350 \mathrm{~m}, \mathrm{Y}-1047633 \mathrm{~m}$ \\
\hline 85 & 114 & 46,05 & 27 & & $\mathrm{X}-605072 \mathrm{~m}, \mathrm{Y}-1047401 \mathrm{~m}$ \\
\hline 86 & 123 & 58,53 & 8 & & $\mathrm{X}-605348 \mathrm{~m}, \mathrm{Y}-1047651 \mathrm{~m}$ \\
\hline 87 & 105 & 45,23 & 25 & & $\mathrm{X}-605372 \mathrm{~m}, \mathrm{Y}-1047647 \mathrm{~m}$ \\
\hline 88 & 115 & 52,08 & 12 & & $\mathrm{X}-605345 \mathrm{~m}, \mathrm{Y}-1047645 \mathrm{~m}$ \\
\hline 89 & 116 & 38,64 & 20 & & $\mathrm{X}-605335 \mathrm{~m}, \mathrm{Y}-1047637 \mathrm{~m}$ \\
\hline 90 & 114 & 36,83 & 30 & & $\mathrm{X}-611666 \mathrm{~m}, \mathrm{Y}-1055842 \mathrm{~m}$ \\
\hline 91 & 89 & 57,26 & 0 & & $X-604891 \mathrm{~m}, \mathrm{Y}-1047662 \mathrm{~m}$ \\
\hline 92 & 81 & 67,80 & 25 & & $\mathrm{X}-606323 \mathrm{~m}, \mathrm{Y}-1048155 \mathrm{~m}$ \\
\hline 93 & 92 & 46,72 & 5 & & $\mathrm{X}-605174 \mathrm{~m}, \mathrm{Y}-1047574 \mathrm{~m}$ \\
\hline 94 & 78 & 38,71 & & & $\mathrm{X}-605312 \mathrm{~m}, \mathrm{Y}-1047613 \mathrm{~m}$ \\
\hline 95 & 106 & 37,23 & 20 & & $\mathrm{X}-605145 \mathrm{~m}, \mathrm{Y}-1047536 \mathrm{~m}$ \\
\hline 96 & 101 & 68,33 & 20 & & $X-605308 m, Y-1047588 m$ \\
\hline 97 & 115 & 53,78 & 15 & & $\mathrm{X}-605345 \mathrm{~m}, \mathrm{Y}-1047634 \mathrm{~m}$ \\
\hline 98 & 110 & 21,43 & 25 & & $\mathrm{X}-605349 \mathrm{~m}, \mathrm{Y}-1047656 \mathrm{~m}$ \\
\hline 99 & 75 & 38,32 & 15 & & $X-605154 \mathrm{~m}, \mathrm{Y}-1047595 \mathrm{~m}$ \\
\hline 100 & 74 & 27,10 & 15 & & $\mathrm{X}-605276 \mathrm{~m}, \mathrm{Y}-1047386 \mathrm{~m}$ \\
\hline 101 & 87 & 48,63 & 5 & & $\mathrm{X}-605227 \mathrm{~m}, \mathrm{Y}-1047385 \mathrm{~m}$ \\
\hline 102 & 88 & 47,53 & 17 & & $\mathrm{X}-605310 \mathrm{~m}, \mathrm{Y}-1047613 \mathrm{~m}$ \\
\hline 103 & 112 & 49,59 & 0 & & $\mathrm{X}-605214 \mathrm{~m}, \mathrm{Y}-1047690 \mathrm{~m}$ \\
\hline 104 & 110 & 44,12 & 26 & & $\mathrm{X}-605361 \mathrm{~m}, \mathrm{Y}-1047645 \mathrm{~m}$ \\
\hline 105 & 111 & 53,70 & 30 & & $X-605347 \mathrm{~m}, \mathrm{Y}-1047646 \mathrm{~m}$ \\
\hline 106 & 120 & 49,14 & 18 & & $\mathrm{X}-605099 \mathrm{~m}, \mathrm{Y}-1047541 \mathrm{~m}$ \\
\hline 107 & 119 & 42,20 & 15 & & $\mathrm{X}-605289 \mathrm{~m}, \mathrm{Y}-1047599 \mathrm{~m}$ \\
\hline 108 & 116 & 22,74 & 22 & & $\mathrm{X}-605365 \mathrm{~m}, \mathrm{Y}-1047633 \mathrm{~m}$ \\
\hline 109 & 121 & 50,57 & 25 & & $\mathrm{X}-605299 \mathrm{~m}, \mathrm{Y}-1047601 \mathrm{~m}$ \\
\hline 110 & 122 & 46,77 & 10 & & $\mathrm{X}-605389 \mathrm{~m}, \mathrm{Y}-1047648 \mathrm{~m}$ \\
\hline 111 & 119 & 46,86 & 12 & & $\mathrm{X}-605302 \mathrm{~m}, \mathrm{Y}-1047698 \mathrm{~m}$ \\
\hline 112 & 116 & 42,84 & 0 & & $\mathrm{X}-605096 \mathrm{~m}, \mathrm{Y}-1047553 \mathrm{~m}$ \\
\hline 113 & 80 & 41,74 & & & $\mathrm{X}-605259 \mathrm{~m}, \mathrm{Y}-1047511 \mathrm{~m}$ \\
\hline 115 & 62 & 47,39 & 30 & & $X-605289 \mathrm{~m}, \mathrm{Y}-1047617 \mathrm{~m}$ \\
\hline
\end{tabular}




\begin{tabular}{|c|c|c|c|c|}
\hline 116 & 74 & 34,90 & 25 & $X-605290 \mathrm{~m}, \mathrm{Y}-1047611 \mathrm{~m}$ \\
\hline 129 & 92 & 29,22 & & $\mathrm{X}-605309 \mathrm{~m}, \mathrm{Y}-1047721 \mathrm{~m}$ \\
\hline 130 & 86 & 45,87 & 0 & $\mathrm{X}-605290 \mathrm{~m}, \mathrm{Y}-1047724 \mathrm{~m}$ \\
\hline 132 & 65 & 38,98 & & $X-605306 m, Y-1047722 m$ \\
\hline 133 & 60 & 6,25 & 0 & $X-605275 \mathrm{~m}, \mathrm{Y}-1047725 \mathrm{~m}$ \\
\hline 134 & 80 & 34,52 & & $X-605395 \mathrm{~m}, \mathrm{Y}-1047774 \mathrm{~m}$ \\
\hline 136 & 140 & 35,38 & & $X-605207 \mathrm{~m}, \mathrm{Y}-1047436 \mathrm{~m}$ \\
\hline 137 & 54 & 26,44 & & $X-605294 \mathrm{~m}, \mathrm{Y}-1047771 \mathrm{~m}$ \\
\hline 145 & 54 & 10,04 & & $X-604990 \mathrm{~m}, \mathrm{Y}-1047645 \mathrm{~m}$ \\
\hline 160 & 126 & 57,3 & 30 & $\mathrm{X}-605356 \mathrm{~m}, \mathrm{Y}-1047641 \mathrm{~m}$ \\
\hline 161 & 58 & 12,46 & 8 & - \\
\hline 162 & 115 & 48,55 & 25 & $X-605346 m, Y-1047646 m$ \\
\hline 163 & 127 & 26,47 & & $X-605341 \mathrm{~m}, \mathrm{Y}-1047650 \mathrm{~m}$ \\
\hline 164 & 91 & 28,20 & 15 & $X-605357 \mathrm{~m}, \mathrm{Y}-1047656 \mathrm{~m}$ \\
\hline 165 & 72 & 26,32 & & $\mathrm{X}-605330 \mathrm{~m}, \mathrm{Y}-1047624 \mathrm{~m}$ \\
\hline 166 & 88 & 55,20 & 8 & $X-605324 m, Y-1047647 m$ \\
\hline 167 & 91 & 31,95 & 5 & $\mathrm{X}-605320 \mathrm{~m}, \mathrm{Y}-1047624 \mathrm{~m}$ \\
\hline 168 & 73 & 37,99 & 5 & $\mathrm{X}-605300 \mathrm{~m}, \mathrm{Y}-1047651 \mathrm{~m}$ \\
\hline 169 & 122 & 49,82 & 15 & $\mathrm{X}-605331 \mathrm{~m}, \mathrm{Y}-1047633 \mathrm{~m}$ \\
\hline 170 & 82 & 16,51 & 5 & $X-605319 m, Y-1047629 m$ \\
\hline 171 & 109 & 57,29 & 10 & $\mathrm{X}-605259 \mathrm{~m}, \mathrm{Y}-1047607 \mathrm{~m}$ \\
\hline 172 & 112 & 45,69 & 15 & $X-605342 \mathrm{~m}, \mathrm{Y}-1047659 \mathrm{~m}$ \\
\hline 173 & 62 & 48,84 & 25 & $X-605294 \mathrm{~m}, \mathrm{Y}-1047637 \mathrm{~m}$ \\
\hline 174 & 113 & 49,55 & 0 & $\mathrm{X}-605311 \mathrm{~m}, \mathrm{Y}-1047642 \mathrm{~m}$ \\
\hline 175 & 115 & 45,82 & 35 & $\mathrm{X}-605326 \mathrm{~m}, \mathrm{Y}-1047637 \mathrm{~m}$ \\
\hline 177 & 85 & 42,24 & 5 & - \\
\hline 186 & 102 & 41,48 & 35 & $X-605104 \mathrm{~m}, \mathrm{Y}-1047553 \mathrm{~m}$ \\
\hline 187 & 65 & 35,42 & 5 & $X-605173 \mathrm{~m}, \mathrm{Y}-1047456 \mathrm{~m}$ \\
\hline 188 & 114 & 52,69 & 5 & $\mathrm{X}-605049 \mathrm{~m}, \mathrm{Y}-1047443 \mathrm{~m}$ \\
\hline 189 & 80 & 70,1 & 25 & $X-605052 \mathrm{~m}, \mathrm{Y}-1047432 \mathrm{~m}$ \\
\hline 190 & 115 & 40,92 & 22 & $X-605178 \mathrm{~m}, \mathrm{Y}-1047478 \mathrm{~m}$ \\
\hline 191 & 87 & 34,10 & 10 & $\mathrm{X}-605035 \mathrm{~m}, \mathrm{Y}-1047372 \mathrm{~m}$ \\
\hline 192 & 91 & 41,16 & 12 & $X-605411 \mathrm{~m}, \mathrm{Y}-1047763 \mathrm{~m}$ \\
\hline 193 & 79 & 35,71 & 15 & $X-605188 m, Y-1047522 m$ \\
\hline 194 & 113 & 52,54 & 22 & $X-605524 \mathrm{~m}, \mathrm{Y}-1047678 \mathrm{~m}$ \\
\hline 195 & 114 & 46,45 & 20 & $X-605172 \mathrm{~m}, \mathrm{Y}-1047482 \mathrm{~m}$ \\
\hline 196 & 82 & 32,62 & & $\mathrm{X}-605355 \mathrm{~m}, \mathrm{Y}-1047776 \mathrm{~m}$ \\
\hline 197 & 75 & 37,50 & 10 & $\mathrm{X}-605375 \mathrm{~m}, \mathrm{Y}-1047769 \mathrm{~m}$ \\
\hline 198 & 104 & 46,18 & 10 & $X-605176 m, Y-1047512 m$ \\
\hline 199 & 65 & 31,62 & 8 & $X-605230 \mathrm{~m}, \mathrm{Y}-1047575 \mathrm{~m}$ \\
\hline 200 & 79 & 28,49 & 14 & $X-605215 \mathrm{~m}, \mathrm{Y}-1047489 \mathrm{~m}$ \\
\hline 201 & 83 & 40,70 & 18 & $\mathrm{X}-605316 \mathrm{~m}, \mathrm{Y}-1047676 \mathrm{~m}$ \\
\hline 204 & 79 & 40,25 & & - \\
\hline 207 & 84 & 11,48 & 8 & $X-605231 \mathrm{~m}, \mathrm{Y}-1047644 \mathrm{~m}$ \\
\hline 208 & 102 & 30,84 & 4 & $X-605308 \mathrm{~m}, \mathrm{Y}-1047621 \mathrm{~m}$ \\
\hline
\end{tabular}




\begin{tabular}{|c|c|c|c|c|c|}
\hline 209 & 102 & 46,63 & 17 & & $X-605236 \mathrm{~m}, \mathrm{Y}-1047657 \mathrm{~m}$ \\
\hline 210 & 75 & 8,29 & 8 & & $\mathrm{X}-605174 \mathrm{~m}, \mathrm{Y}-1047465 \mathrm{~m}$ \\
\hline 213 & 105 & 45,37 & & & $X-605343 \mathrm{~m}, \mathrm{Y}-1047656 \mathrm{~m}$ \\
\hline 214 & 72 & 47,39 & & & $X-605299 \mathrm{~m}, \mathrm{Y}-1047633 \mathrm{~m}$ \\
\hline 218 & 112 & 39,70 & & & $X-605116 m, Y-1047441 m$ \\
\hline 224 & 88 & 45,83 & 17 & & $X-605195 \mathrm{~m}, \mathrm{Y}-1047386 \mathrm{~m}$ \\
\hline 225 & 83 & 41,32 & 16 & & $\mathrm{X}-605061 \mathrm{~m}, \mathrm{Y}-1047491 \mathrm{~m}$ \\
\hline 226 & 113 & 56,83 & 13 & & $\mathrm{X}-605040 \mathrm{~m}, \mathrm{Y}-1047387 \mathrm{~m}$ \\
\hline 228 & 64 & 28,04 & 12 & & $X-605987 \mathrm{~m}, \mathrm{Y}-1041691 \mathrm{~m}$ \\
\hline 229 & 64 & 10,99 & & & $X-605056 \mathrm{~m}, \mathrm{Y}-1047394 \mathrm{~m}$ \\
\hline 231 & 76 & 12,79 & 10 & & $X-605899 m, Y-1041733 m$ \\
\hline 232 & 79 & 34,52 & 25 & & $X-605937 \mathrm{~m}, \mathrm{Y}-1041693 \mathrm{~m}$ \\
\hline 234 & 80 & 45,63 & 22 & & $\mathrm{X}-606044 \mathrm{~m}, \mathrm{Y}-1041681 \mathrm{~m}$ \\
\hline 235 & 80 & 43,41 & 5 & & $X-605910 \mathrm{~m}, \mathrm{Y}-1041594 \mathrm{~m}$ \\
\hline 237 & 108 & 50,74 & & & $X-605308 \mathrm{~m}, \mathrm{Y}-1047635 \mathrm{~m}$ \\
\hline 238 & 105 & 44,10 & 10 & & $X-605320 \mathrm{~m}, \mathrm{Y}-1047632 \mathrm{~m}$ \\
\hline 239 & 115 & 37,50 & 10 & & $\mathrm{X}-605320 \mathrm{~m}, \mathrm{Y}-1047632 \mathrm{~m}$ \\
\hline 244 & 88 & 42,58 & 10 & & - \\
\hline 263 & 65 & 15,55 & 15 & & $X-605353 \mathrm{~m}, \mathrm{Y}-1047651 \mathrm{~m}$ \\
\hline 264 & 51 & 12,30 & & & $X-605313 \mathrm{~m}, \mathrm{Y}-1047639 \mathrm{~m}$ \\
\hline 265 & 50 & 7,55 & 2 & & $\mathrm{X}-605299 \mathrm{~m}, \mathrm{Y}-1047585 \mathrm{~m}$ \\
\hline 266 & 54 & 15,86 & 12 & & $X-605358 m, Y-1047642 m$ \\
\hline 267 & 89 & 50,01 & 22 & & $\mathrm{X}-605346 \mathrm{~m}, \mathrm{Y}-1047639 \mathrm{~m}$ \\
\hline 268 & 94 & 26,09 & 5 & & $\mathrm{X}-605358 \mathrm{~m}, \mathrm{Y}-1047643 \mathrm{~m}$ \\
\hline 270 & 161 & 71,25 & 12 & & $\mathrm{X}-605341 \mathrm{~m}, \mathrm{Y}-1047621 \mathrm{~m}$ \\
\hline 271 & 84 & 58,55 & 20 & & $\mathrm{X}-605341 \mathrm{~m}, \mathrm{Y}-1047621 \mathrm{~m}$ \\
\hline 272 & 78 & 42,34 & 30 & A839 & $X-605287 \mathrm{~m}, \mathrm{Y}-1047651 \mathrm{~m}$ \\
\hline 273 & 90 & 43,65 & 16 & A841 & $X-605034 \mathrm{~m}, \mathrm{Y}-1047676 \mathrm{~m}$ \\
\hline 274 & 83 & 43,78 & & A842 & $\mathrm{X}-605228 \mathrm{~m}, \mathrm{Y}-1047665 \mathrm{~m}$ \\
\hline 275 & 75 & 9,48 & 15 & A844 & $X-605247 \mathrm{~m}, \mathrm{Y}-1047646 \mathrm{~m}$ \\
\hline 276 & 107 & 56,9 & & A845 & $X-605271 \mathrm{~m}, \mathrm{Y}-1047674 \mathrm{~m}$ \\
\hline 277 & 79 & 55,08 & 15 & A846 & $X-605298 \mathrm{~m}, \mathrm{Y}-1047746 \mathrm{~m}$ \\
\hline 278 & 96 & 75,17 & 15 & A847 & $X-605270 \mathrm{~m}, \mathrm{Y}-1047667 \mathrm{~m}$ \\
\hline 279 & 90 & 64,65 & 25 & A848 & $\mathrm{X}-605151 \mathrm{~m}, \mathrm{Y}-1047827 \mathrm{~m}$ \\
\hline 280 & 69 & 43,07 & 10 & A849 & $\mathrm{X}-605422 \mathrm{~m}, \mathrm{Y}-1047789 \mathrm{~m}$ \\
\hline 281 & 85 & 52,98 & 16 & A 850 & $\mathrm{X}-605300 \mathrm{~m}, \mathrm{Y}-1047732 \mathrm{~m}$ \\
\hline 282 & 77 & 42,7 & 32 & A851 & $X-605263 \mathrm{~m}, \mathrm{Y}-1047661 \mathrm{~m}$ \\
\hline 283 & 79 & 50,29 & & A852 & $X-605753 \mathrm{~m}, \mathrm{Y}-1049679 \mathrm{~m}$ \\
\hline 284 & 105 & 39,22 & 38 & A853 & $\mathrm{X}-605335 \mathrm{~m}, \mathrm{Y}-1047865 \mathrm{~m}$ \\
\hline 285 & 75 & 41,5 & & A857 & $X-605335 \mathrm{~m}, \mathrm{Y}-1047719 \mathrm{~m}$ \\
\hline 286 & 75 & 44,58 & 12 & A859 & $\mathrm{X}-605337 \mathrm{~m}, \mathrm{Y}-1047733 \mathrm{~m}$ \\
\hline 287 & 67 & 17,53 & 14 & A861 & $\mathrm{X}-605302 \mathrm{~m}, \mathrm{Y}-1047726 \mathrm{~m}$ \\
\hline 288 & 84 & 17,53 & 22 & A862 & $\mathrm{X}-605304 \mathrm{~m}, \mathrm{Y}-1047787 \mathrm{~m}$ \\
\hline 289 & 78 & 48,3 & & A865 & $\mathrm{X}-604971 \mathrm{~m}, \mathrm{Y}-1047654 \mathrm{~m}$ \\
\hline 290 & 117 & 58,8 & 15 & A840 & - \\
\hline
\end{tabular}


Jedno z tradičních dělení hrotů šípů vychází ze způsobu jejich upevnění k dřevěnému střelišti šípu. V souboru jsou pak zastoupeny jak hroty, jež se upevňovaly pomocí trnu ( $20 \mathrm{ks})$, tak hroty vybavené tulejkou (168 ks). Mezi hroty vybavenými trnem převládají exempláře se štíhlým tvarem těla rombického průřezu (obr. 8). Jejich trny jsou sklepány zhruba do kruhového průřezu. Maximální šířka a tloušt'ka těchto hrotů je situována v horní části jejich těla. Zařadit je lze k typu B11 podle A. Ruttkaye (1976, 327), popř́ípadě typu A II podle R. Krajíce $(2003,186)$, respektive k typům D 2-4 a D 2-5 B. Zimmermanna (2000, 75-76). Zpravidla bývají tyto hroty řazeny $\mathrm{k}$ munici sloužící ke střelbě $\mathrm{z}$ luku. Tento předpoklad vychází z jejich tvaru a zejména z jejich nižší váhy. Již R. Prihoda (1932, 43-66) uvažoval o hranici 25 gramů, která by mohla odlišovat obě skupiny šipek. Na podobném principu poměru délky a váhy je založen i výpočet T. Durdíka $(1983,18)$, který rovněž odlišuje obě skupiny mezní hodnotou poměru 3. Oba předpoklady však nelze přejímat zcela bez výhrad, jak ostatně doložil například B. Zimmermann (2000, 20-21). Přesto v př́padě rychmberských hrotů s trnem zjišt'ujeme, že jejich celková váha skutečně nepřevyšuje hranici 22 gramů a kolísá od 7,55 do 21,49 g, přičemž průměrná váha činí 16,18 g. ${ }^{3}$ Autoři, kteří tyto hroty dříve publikovali, je chronologicky řadí do širokého časového rámce od 11. až po 14. století (Zimmermann 2000, 75; Serdon 2005, 124). Těžiště výskytu se pak klade zejména do horizontu 13. a 14. století, nebot' právě v kontextu lokalit řazených do tohoto období bývají nejčastěji přítomny (Krajíc 2003, 189; Zimmermann 2000, 76). Přesto lze počítat s jejich užíváním ještě na počátku 15. století, jelikož bývají obsaženy i v souborech spojovaných s válečnými událostmi husitského období. V kontextu východních Čech lze tyto hroty nalézt v souborech spadajících do období 13.-14. století například u hradů Bolkova (Hejna 1962, 462, obr. 4:2), Božanova (Drnovský-Mazáčková-Šrámek 2019, 580, obr. 17) či Bradla (Hejna 1974, 393, obr. 13:3-5, 9-11). Přítomny jsou i v kolekcích sahajících do období husitských válek, jako např́íklad z hradu Červené Hory obléhaného v letech 1421 a 1427 (Drnovský 2018, 160, obr. 208:1-2), hradu Mokřice (Drnovský 2021) či Vízmburku zaniklého v roce 1447 (Mazáčková 2013, 165, tab. 71:21-24). V souboru hrotů spojených s dobýváním hradu Sionu roku 1437 se však nevyskytují (Koscelník-Kypta-Savková 2013, 583-589).

Do skupiny hrotů s trnem je možno zařadit i solitérní silně zkorodovaný exempláŕ (R 136; obr. 8), který se vyznačuje dlouhým tělem (140 mm, váha 35,38 g). Podle průřezu s nevýrazným rozš́iřením v polovině své délky by snad mohl být zařazen k hrotům typu B10 A. Ruttkaye (1976, 331) či typu D 1-1 podle B. Zimmermanna (2000, 73-74). Oba autoři kladou výskyt těchto hrotů do období 11.-13. století.

Mezi hroty, které byly opatřeny tulejí, jasně dominují dvě vzájemně blízké skupiny, pro které je charakteristická celková robustnost a rombický průřez těla (obr. 4, 5, 6, 7). Liší se od sebe pouze tvarem těla. Zatímco u první skupiny přechází hrot plynule v tulej, u druhé skupiny je tento přechod více zaškrcený a rovněž ty to hroty mají i více plochý průřez. První skupina je zastoupena 64 exempláři, které odpovídají hrotům typu T 2-5 dle B. Zimmermanna (2000, 51-53), poprrípadě typu B IIb R. Krajíce $(2003,184)$ či typu H podle V. Serdon $(2005,104-105)$. Druhá skupina je prŕtomna v 82 kusech a je možné ji zařadit k typu hrotů T 2-4 dle B. Zimmermanna (2000, 49-50), respektive typu B IIa R. Krajíce $(2003,184)$ či typu F podle V. Serdon $(2005,104-105)$. V př́ípadě těchto hrotů panuje obecná shoda, že se jedná o munici sloužící ke střelbě ze samostř́lu. Váhová škála rychmberských hrotů tomuto závěru odpovídá. Váha hrotů typu T 2-4 se pohybuje od 27,74 do 53,70 g, průměrná váha pak činí 46,43 g. Hmotnost hrotů typu T 2-5 kolísá od 27,29 do $68,33 \mathrm{~g}$, přičemž průměrná váha činí $42,20 \mathrm{~g}$. V př́ípadě těchto dvou skupin hrotů se jedná o jeden z nejrozšířenějších druhů střeliva, jejichž těžiště výskytu je kladeno zejména do období 14.-15. století (Krajíc 2003, 187; Serdon 2005, 101-102; Zimmermann 2000, 47). V českém prostředí je charakteristický především jejich výskyt $\mathrm{v}$ rámci lokalit spojených s husitskými válkami a dobou vlády Jiř́iho z Poděbrad. Tomu odpovídá jejich př́ítomnost na okolních lokalitách, např́íklad na Červené Hoře (Drnovský 2018, 160, obr. 208:3-22), Lichnici (Frolík 2002, 406-407, obr. 5:18-23;

3 Hodnoty jsou vypočítávány pouze u kompletních jedinců. 

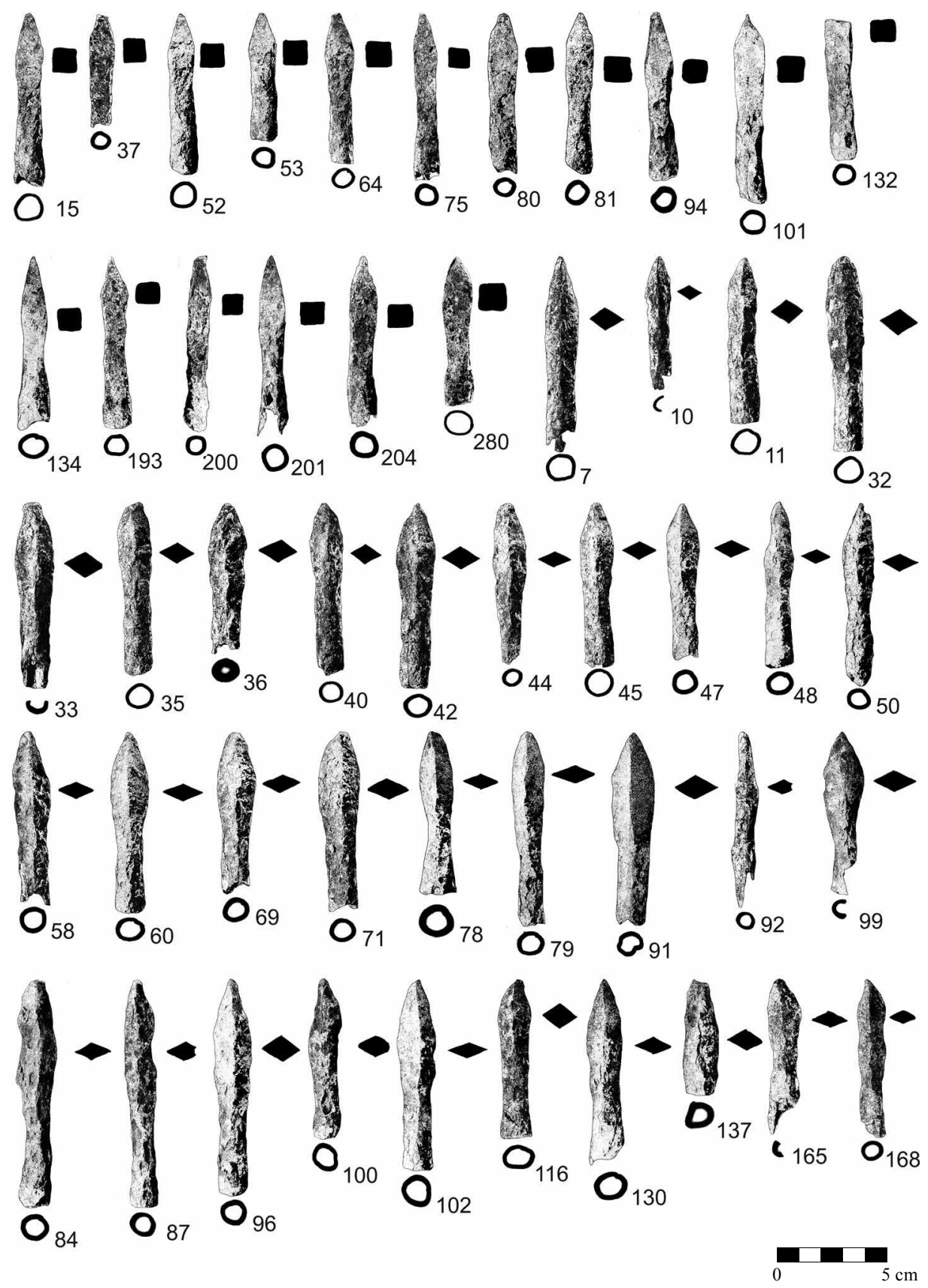

Obr. 4. Hrad Rychmberk. Hroty šípů. Čísla odpovídají označení nálezů v textu.

Abb. 4. Burg Rychmberk. Pfeilspitzen. Die Nummern entsprechen der Kennzeichnung der Funde im Text. 

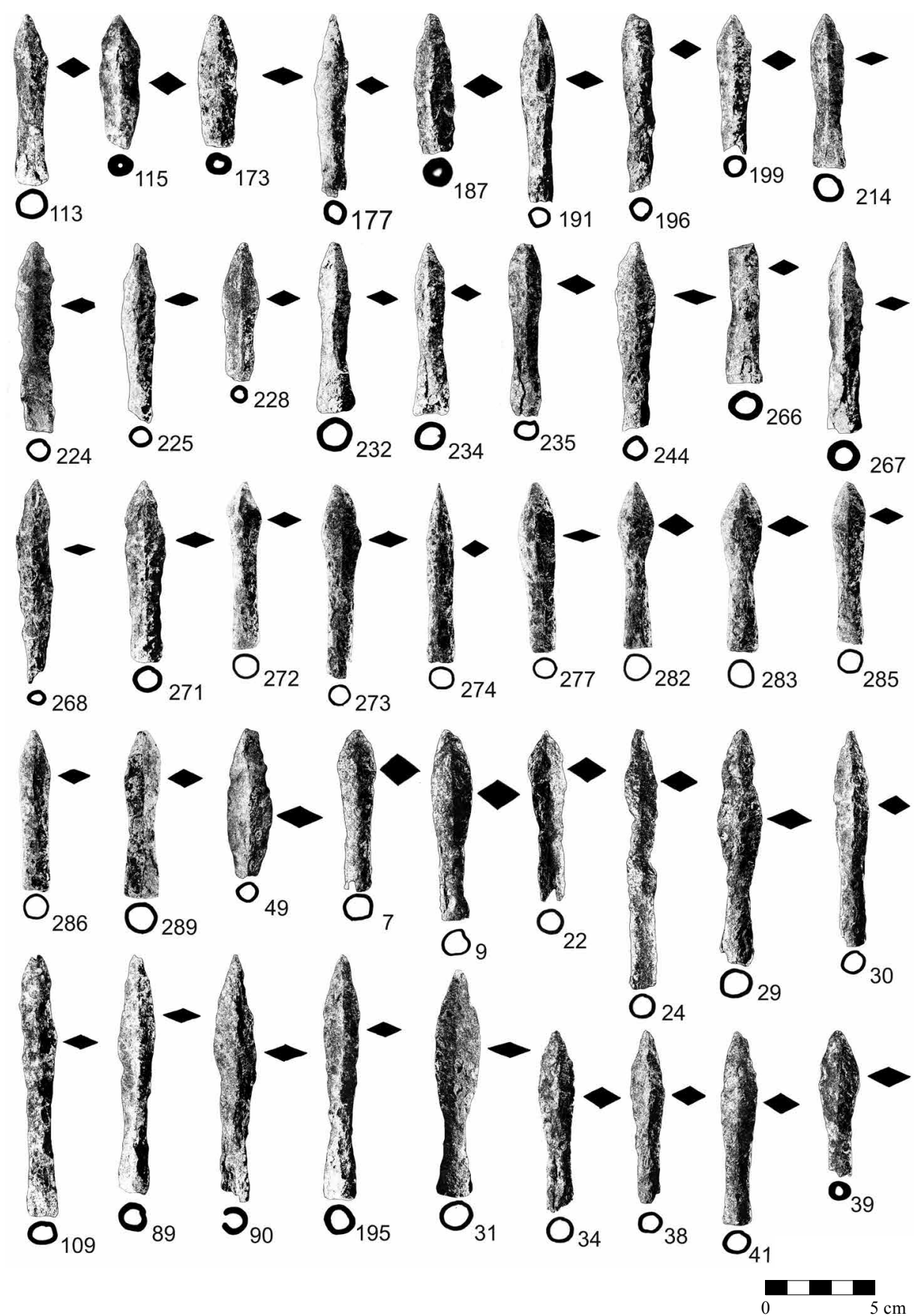

Obr. 5. Hrad Rychmberk. Hroty šípů. Čísla odpovídají označení nálezů v textu.

Abb. 5. Burg Rychmberk. Pfeilspitzen. Die Nummern entsprechen der Kennzeichnung der Funde im Text. 

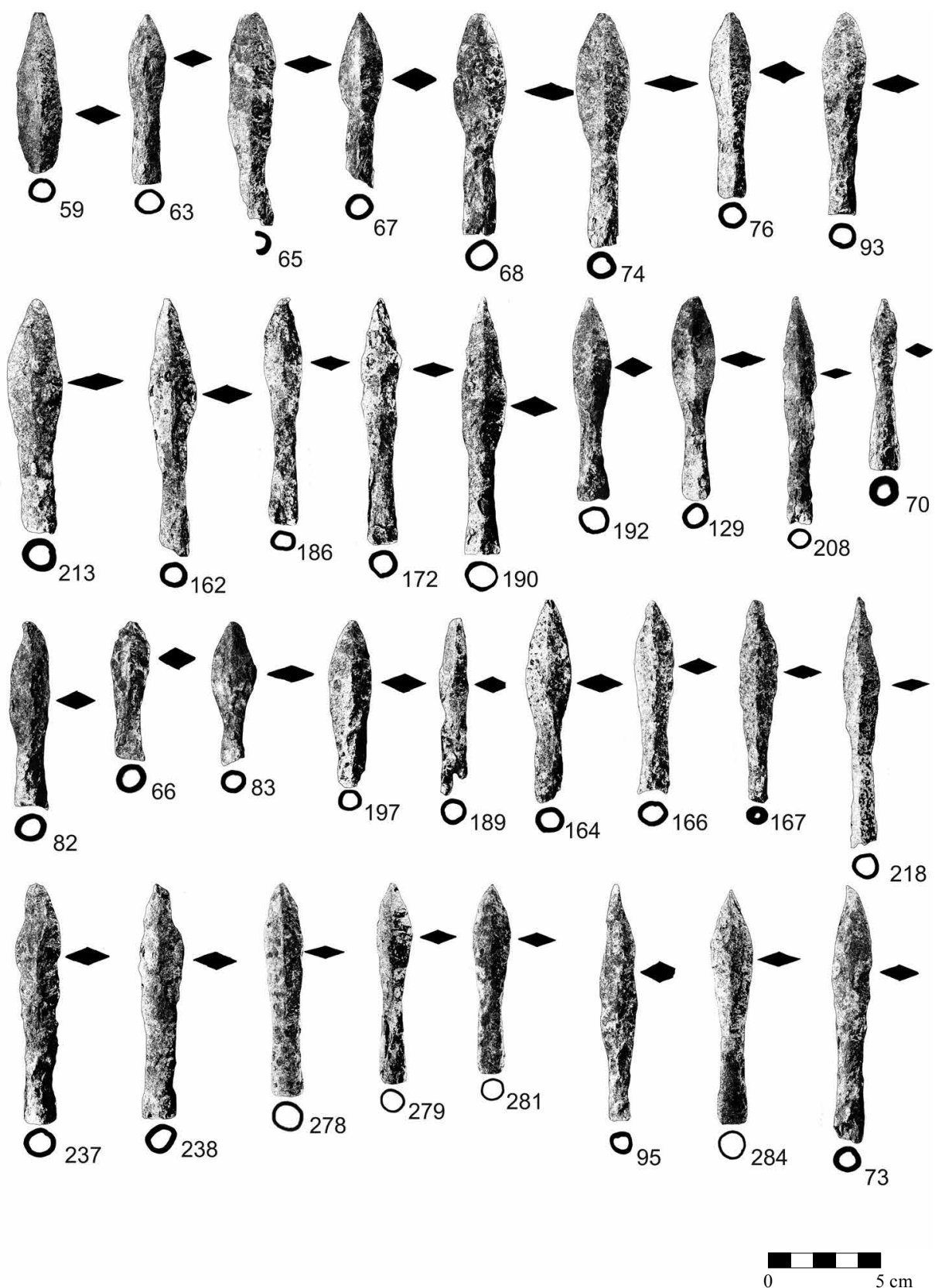

Obr. 6. Hrad Rychmberk. Hroty šípů. Čísla odpovídají označení nálezů v textu.

Abb. 6. Burg Rychmberk. Pfeilspitzen. Die Nummern entsprechen der Kennzeichnung der Funde im Text. 

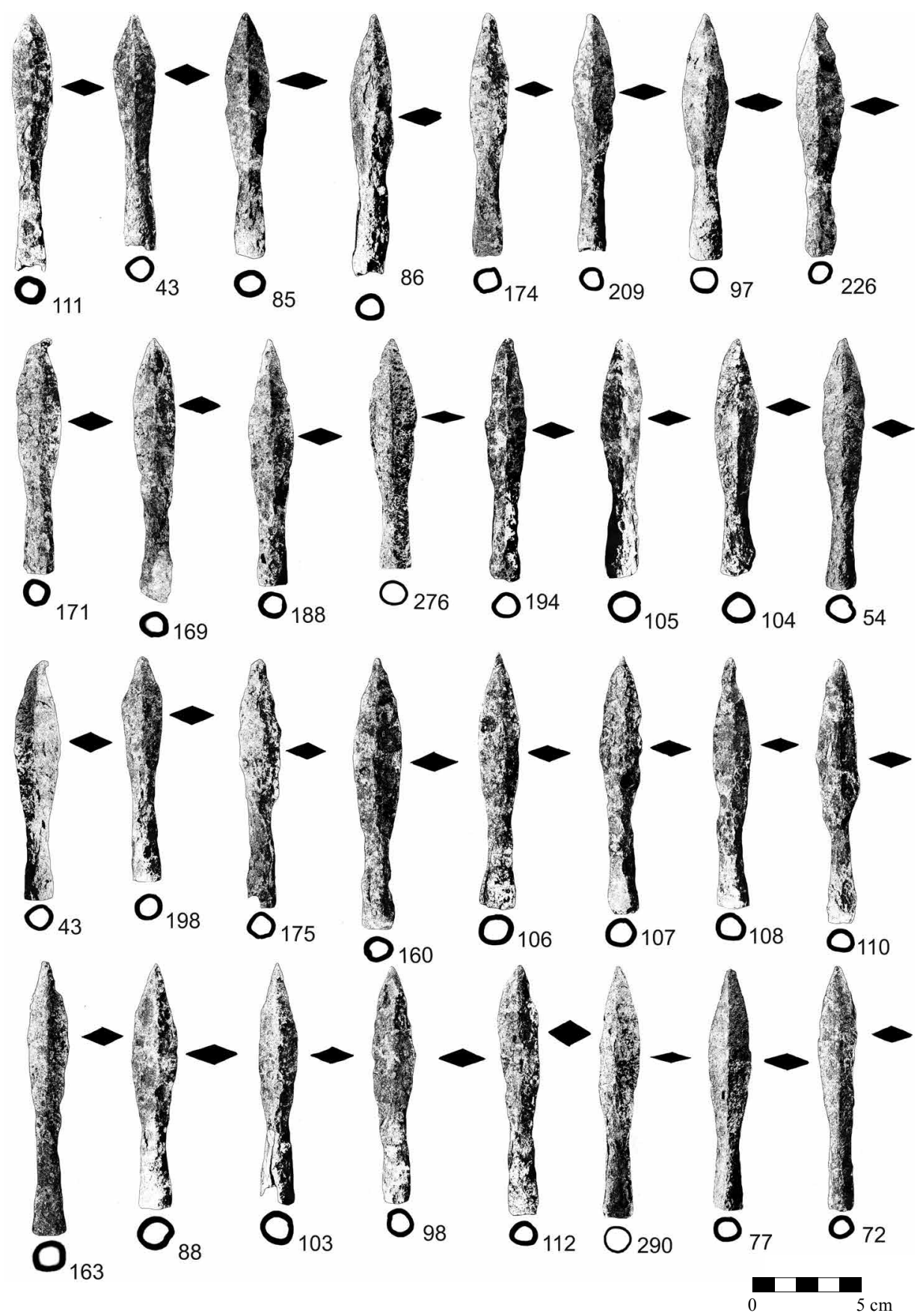

Obr. 7. Hrad Rychmberk. Hroty šípů. Čísla odpovídají označení nálezů v textu.

Abb. 7. Burg Rychmberk. Pfeilspitzen. Die Nummern entsprechen der Kennzeichnung der Funde im Text. 

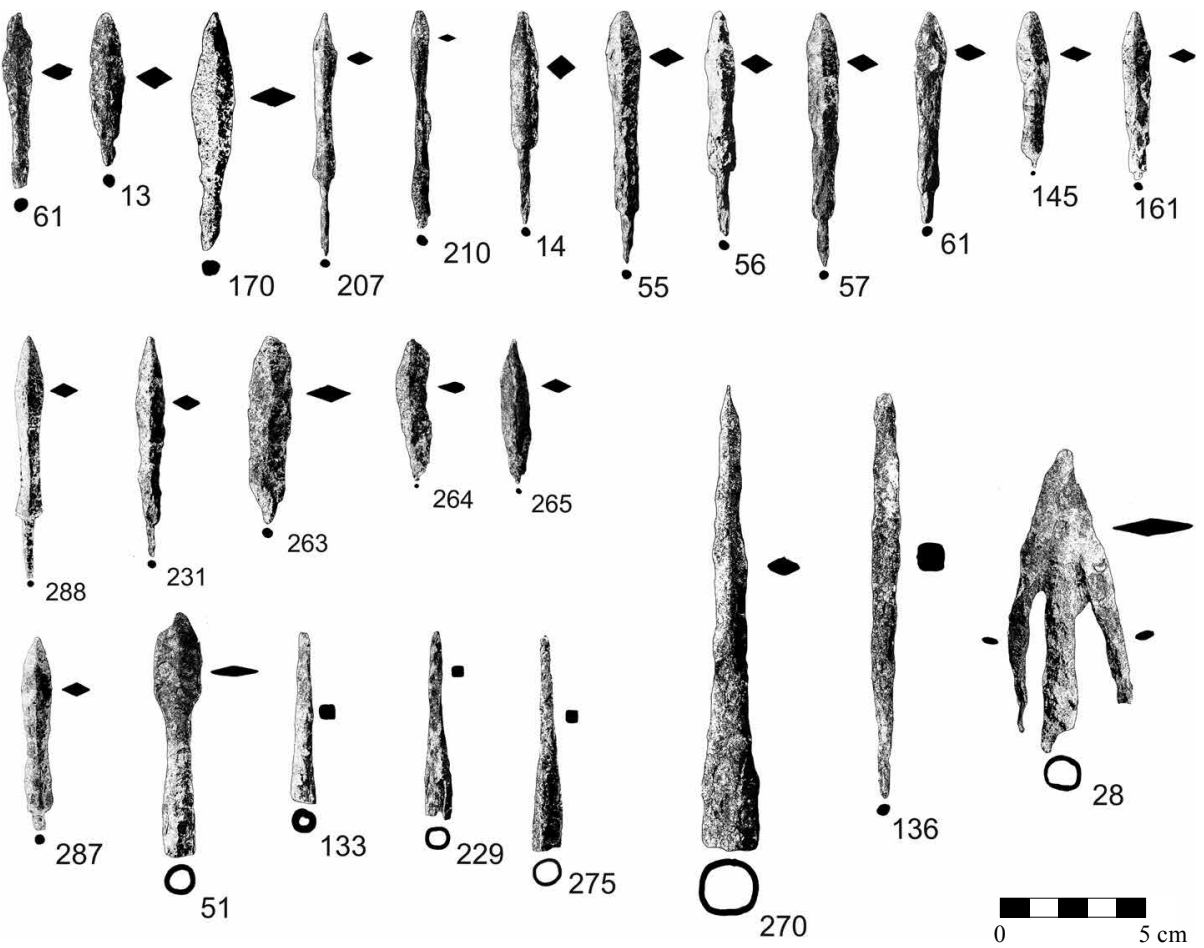

Obr. 8. Hrad Rychmberk. Hroty šípů. Čísla odpovídají označení nálezů v textu.

Abb. 8. Burg Rychmberk. Pfeilspitzen. Die Nummern entsprechen der Kennzeichnung der Funde im Text.

Frolík-Musil 2013, 166, obr. 7:3-5), Mokřici (Drnovský 2021), Sionu (Koscelník-Kypta-Savková 2013, 583-589, obr. 7-8) a Vízmburku (Mazáčková 2013, 165, tab. 72:21).

Další skupinu hrotů střel s tulejí představují exempláře s kvadratickým průřezem těla. V kolekci se vyskytují v 17 př́padech (obr. 4). Jejich hmotnostní škála odpovídá dvěma předchozím typům, váha se pohybuje od 29,36 po $48,63 \mathrm{~g}$, přičemž průměrná váha dosahuje $38,81 \mathrm{~g}$. Tuto munici je možno zařadit jednoznačně k typu T 1-5 dle B. Zimmermanna $(2000,46-48)$, případně typu B III R. Krajíce (2003, 185) či typu E podle V. Serdon (2005, 101-102). Chronologický výskyt těchto hrotů je obdobný jako u předchozích typů.

Další nálezy hrotů s tulejí se již vyskytují ve výrazně menších počtech. Celkem čtyři hroty mají kvadratický průřez těla, které postrádá výraznější rozšíření (obr. 8). Úzké mírně kónické tělo šípu tak končí až hrotem. Typologicky je možno tyto hroty přiřadit typu 3 dle A. Ruttkaye $(1976,328)$ či T 1-3 podle B. Zimmermanna (2000, 41-42). Zatímco první tři hroty (R 133, 229, 275) svými rozměry a váhou odpovídají spíše lukostřelecké munici, čtvrtý hrot (R 270) je se svojí délkou $161 \mathrm{~mm}$ nejdelším exemplářem souboru. Při maximální šířce tuleje $18 \mathrm{~mm}$ by se již mohlo jednat o hrot střely určené do větších hradebních kuší, či spíše válečných strojů. A. Ruttkay (1976, 328) předpokládá užívání těchto tvarů hrotů v širokém časovém rozmezí od 10. do 15 . století, kdy se vyskytují již spíše větší formy určené ke střelbě z kuší, B. Zimmermann (2000, 41-42) pak těžiště jejich výroby klade do doby 10.-12. století.

Jedním exemplářem (R 28) je zastoupen masivní hrot se zpětnými křidélky (obr. 8). Tvarově odpovídá typu A1d podle A. Ruttkaye $(1976,328)$, prŕípadně T 5-8 podle B. Zimmermanna (2000, 64-66), typu E podle V. Serdon (2005, 118-119) nebo typu B IVa R. Krajíce (2003, 187). Tento 
druh hrotů se objevuje v období 13.-16. století (Krajíc 2003, 187; Zimmermann 2000, 64-66). Vzhledem $\mathrm{k}$ jeho rozměrům a váze $(105 \mathrm{~mm}, 48,51 \mathrm{~g})$ se v rychmberském nálezu jedná o hrot šípu určený ke střelbě z kuše.

Jedním zástupcem (R 51) je rovněž zastoupen drobný tulejový hrot, který se vyznačuje dlouhou tulejí, která přechází v hrot s maximálním rozšířením v polovině své délky (obr. 8). Samotný hrot se rovněž vyznačuje menší výškou těla. Hrot lze zařadit k typu T 5-5 podle B. Zimmermanna (2000, 63-64), alternativně k typu C dle V. Serdon (2005, 117-118). Oba autoři jejich výskyt kladou v prostředí západní Evropy do období 11.-14. století. Soudě podle rozměrů ( $85 \mathrm{~mm}, 19,43 \mathrm{~g})$, se patrně jedná o lukostřelecký hrot.

Kromě výše uvedených hrotů, které byly pojednány souhrnně, se ještě zastavíme u zvláštních exemplářù. Prvním je hrot šípu s tulejí a kvadratickým průřezem těla (R 132). Horní část hrotu chybí, dle charakteru horní plochy hrotu je pravděpodobné, že se jednalo o hrot, který byl kovářsky upraven tak, že byl naseknut, aby horní partie hrotu držela pouze za okraj jedné ze stěn (obr. 4). Tato úprava zapř́íčinila, že se hrot po dopadu rozlomil. Na našem území prvně tuto úpravu hrotů popsala J. Mazáčková na nálezech z hradu Rokštejna (Krejsová 2007; Mazáčková 2012, 306).

V souboru se dále nachází skupina hrotů šipek, jež vykazuje nápadnou morfologickou shodu. ${ }^{4}$ Jedná se o hroty s rombickým průřezem a zúženým tělem na přechodu k tuleji. Tato skupina 32 hrotů je shodná v metrických vlastnostech a také tvarování oblouku hrotu (obr. 7). Tyto hroty šípů by tak snad bylo množné označit za munici pocházející ze stejné produkce.

Při celkovém posouzení kolekce hrotů šípů můžeme uvést, že jasně převládají exempláře s tulejí. Zastoupeny jsou zejména typy ( 86 \%), které jsou oprávněně označovány jako munice sloužící ke střelbě ze samostřílů (graf 1). Ačkoliv u některých typů lze sledovat výskyt již před 13. stoletím, lze se spíše na základě historických údajů držet zařazení naší kolekce v rozmezí 13. a 15. století. Pro rychmberský soubor lze jako analogie uvést zejména nálezy z lokalit spojených $\mathrm{s}$ obdobím husitských válek a $\mathrm{s}$ následným poděbradským obdobím. Zmiňme zvláště soubory z hradů Mokřice (Drnovský 2021), Sionu (Koscelník-Kypta-Savková 2013), Vízmburku (Mazáčková 2013) a Zítkova u Chocně (Vích 2017).

\subsection{Projektily palných zbraní}

Druhou početnou skupinu nálezů tvoří projektily palných zbraní, kterých bylo objeveno celkem 76 kusů (tab. 3). Při základním dělení jejich tvaru lze vyčlenit čtrnáct projektilů kulovitého tvaru a 56 projektilů válcovitého tvaru, v kolekci dominujících (obr. 9). Šest projektilů nemohlo být $\mathrm{z}$ důvodu deformace způsobené dopadem morfologicky určeno. Průměry kulovitých a válcovitých projektilů je možné rozdělit do velikostních kategorií (graf 2). Pro kulovité projektily jsou nejčastěji zastoupeny průměry 17 a $18 \mathrm{~mm}(8 \mathrm{ks})$, zbylé hodnoty $(16,19,21,25$ a 49) se objevují vždy u jednoho exempláře. Ačkoliv je válcovitých projektilů řádově čtyřikrát více než kulovitých, $\mathrm{v}$ zásadě se $\mathrm{v}$ trendu zastoupených ráží vzájemně neliší. Opět jasně převládají projektily o průměru 17 a $18 \mathrm{~mm}(37 \mathrm{ks})$. Nižší počty jsou zaznamenány pro hodnoty $15 \mathrm{~mm}(2 \mathrm{ks})$ a $16 \mathrm{~mm}$ (2 ks). Z vyšších průměrů je pak čtyřikrát zastoupena hodnota $19 \mathrm{~mm}$, dvakrát $20 \mathrm{~mm}$ a $22 \mathrm{~mm}$. Po jednom zástupci lze metrický výčet uzavř́ít jedinci o průměrech 23 a 26 mm. Projektil R $185 \mathrm{~s}$ nejvyšším průměrem lze oprávněně přiřadit $\mathrm{k}$ munici, která byla použíána pro střelbu z lafetovaných palných zbraní. Rozhodnout, zda zbylé projektily sloužily ke střelbě z lehčích typů palných zbraní (napřr. píštaly), či ze středních palných zabraní (např. hákovnice), je problematické. Jednak se jedná o podkaliberní střelivo, které bylo do hlavní nabíjeno obalené organickým obalem, a zároveň známe píštaly i hákovnice s kolísajícími rážemi (Durdík 1954, 75; Frýda 1988; Novobilský 2008, 84; Strzyż 2011, 15-26). Svojí metrikou se posuzovaný soubor neliší od jiných kolekcí. Z 51 projektilů nalezených u hradu Červené Hory obléhaného na počátku husitských

4 Hroty R 43, 54, 72, 73, 77, 85, 86, 95, 96, 97, 103, 105, 106, 107, 108, 110, 111, 112, 160, 163, 169, 171, 174, 175, 188, 194, 196, 209, 226, $284,290$. 


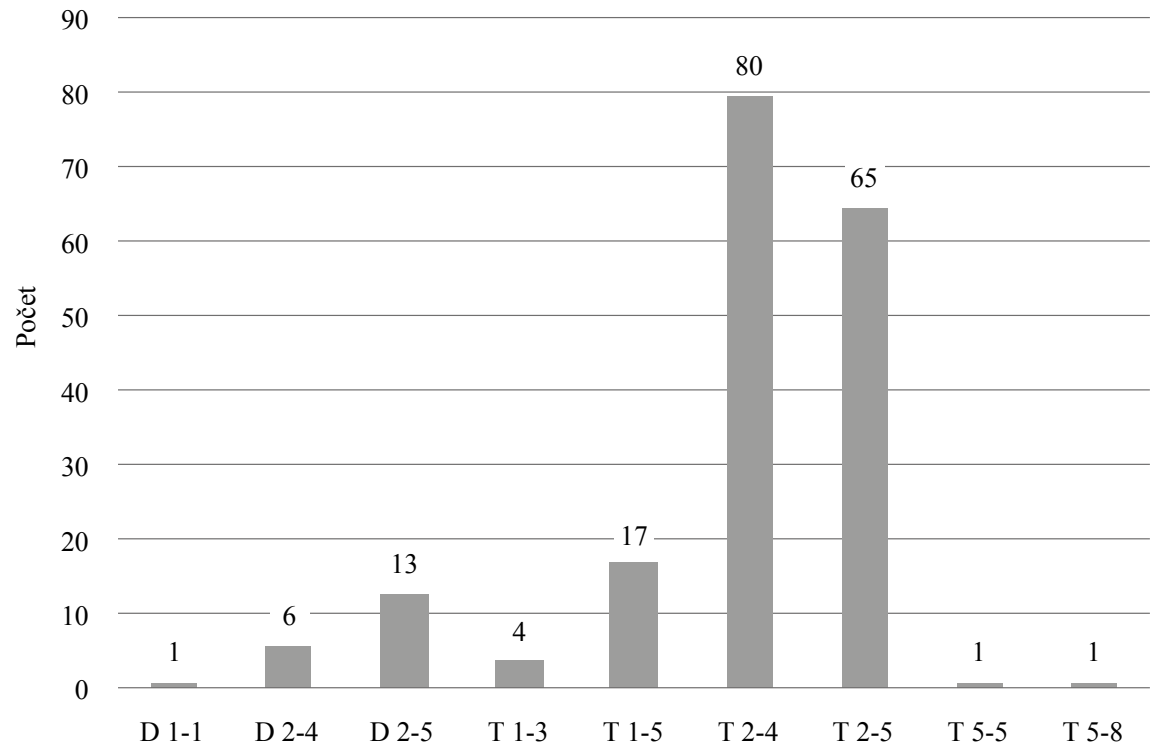

Graf 1. Zastoupení jednotlivých typů hrotů. Typologie dle B. Zimmermanna (2000).

Diagramm 1. Darstellung des Vorkommens der einzelnen Typen von Geschossspitzen. Typologie nach B. Zimmermann (2000).

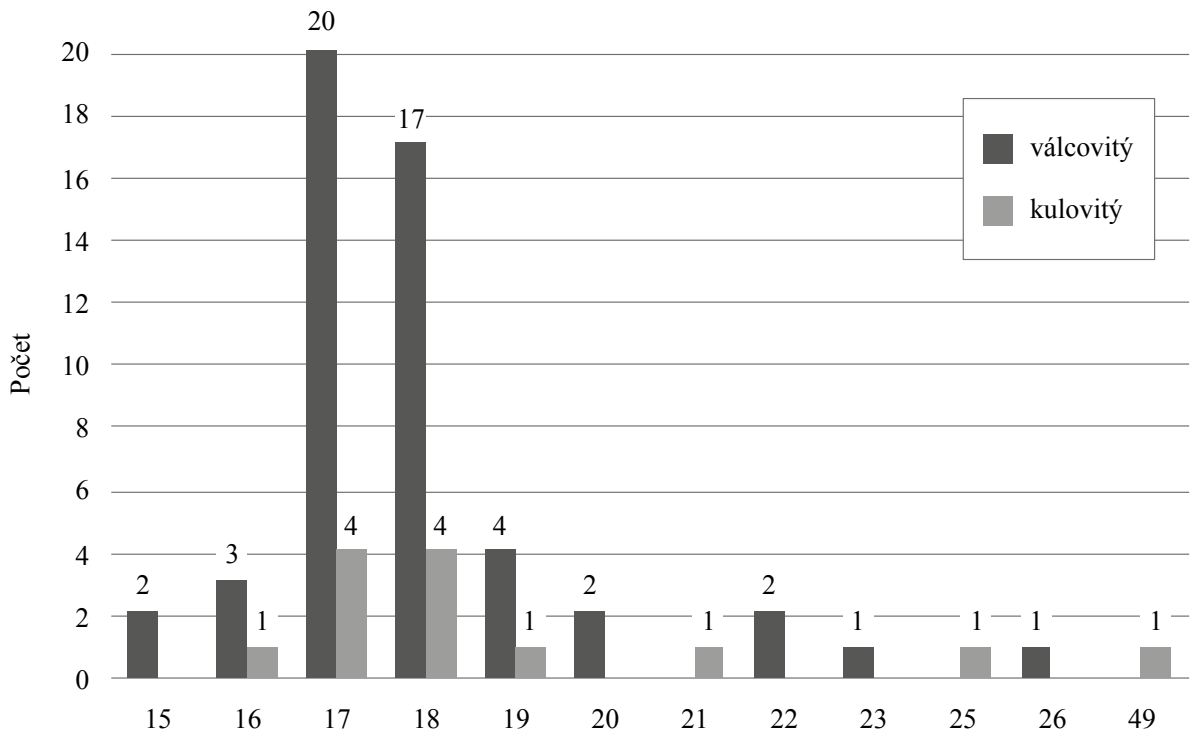

Průměr projektilu (mm)

Graf 2. Zastoupení průměrů jednotlivých projektilů palných zbraní v závislosti na jejich tvaru.

Diagramm 2. Darstellung des Vorkommens der Durchmesser der einzelnen Feuerwaffenprojektile in Abhängigkeit von ihrer Form. 
Tab. 3. Projektily palných zbraní. Metrické, materiálové a nálezové vlastnosti.

Tab. 3. Feuerwaffenprojektile. Metrische, Material- und Fundeigenschaften.

\begin{tabular}{|c|c|c|c|c|c|c|}
\hline číslo nálezu & tvar & průměr (mm) & váha $(\mathrm{g})$ & hloubka & materiál & JTSK \\
\hline 25 & válec & 23 & 20,24 & & $\mathrm{~Pb}$ & $\mathrm{X}-605321 \mathrm{~m}, \mathrm{Y}-1047762 \mathrm{~m}$ \\
\hline 117 & válec & 17 & 35,37 & & $\mathrm{~Pb}+\mathrm{Fe}$ & $\mathrm{X}-605249 \mathrm{~m}, \mathrm{Y}-1047384 \mathrm{~m}$ \\
\hline 118 & válec & 15 & 22,86 & 14 & $\mathrm{~Pb}$ & $\mathrm{X}-605249 \mathrm{~m}, \mathrm{Y}-1047384 \mathrm{~m}$ \\
\hline 119 & válec & 17 & 27,09 & 14 & $\mathrm{~Pb}$ & $\mathrm{X}-605309 \mathrm{~m}, \mathrm{Y}-1047612 \mathrm{~m}$ \\
\hline 120 & válec & 17 & 18,82 & 30 & $\mathrm{~Pb}$ & $\mathrm{X}-605310 \mathrm{~m}, \mathrm{Y}-1047596 \mathrm{~m}$ \\
\hline 121 & válec & 18 & 31,39 & 10 & $\mathrm{~Pb}$ & $\mathrm{X}-605408 \mathrm{~m}, \mathrm{Y}-1047688 \mathrm{~m}$ \\
\hline 122 & válec & - & 24,39 & 12 & $\mathrm{~Pb}$ & $\mathrm{X}-605341 \mathrm{~m}, \mathrm{Y}-1047627 \mathrm{~m}$ \\
\hline 123 & válec & 17 & 19,19 & & $\mathrm{~Pb}+\mathrm{Fe}$ & $\mathrm{X}-605271 \mathrm{~m}, \mathrm{Y}-1047593 \mathrm{~m}$ \\
\hline 124 & válec & 17 & 27,64 & 10 & $\mathrm{~Pb}+\mathrm{Fe}$ & $\mathrm{X}-605316 \mathrm{~m}, \mathrm{Y}-1047620 \mathrm{~m}$ \\
\hline 125 & válec & 15 & 24,99 & 10 & $\mathrm{~Pb}+\mathrm{Fe}$ & $\mathrm{X}-605288 \mathrm{~m}, \mathrm{Y}-1047615 \mathrm{~m}$ \\
\hline 126 & válec & 17 & 22,98 & 15 & $\mathrm{~Pb}+\mathrm{Fe}$ & $\mathrm{X}-605277 \mathrm{~m}, \mathrm{Y}-1047598 \mathrm{~m}$ \\
\hline 127 & válec & 17 & 32,98 & 15 & $\mathrm{~Pb}+\mathrm{Fe}$ & $\mathrm{X}-605301 \mathrm{~m}, \mathrm{Y}-1047576 \mathrm{~m}$ \\
\hline 128 & válec & 17 & 47,55 & 12 & $\mathrm{~Pb}+\mathrm{Fe}$ & $\mathrm{X}-605396 \mathrm{~m}, \mathrm{Y}-1047661 \mathrm{~m}$ \\
\hline 138 & válec & 19 & 42,68 & & $\mathrm{~Pb}$ & $\mathrm{X}-605120 \mathrm{~m}, \mathrm{Y}-1047374 \mathrm{~m}$ \\
\hline 139 & válec & 16 & 15,57 & & $\mathrm{~Pb}$ & $\mathrm{X}-605329 \mathrm{~m}, \mathrm{Y}-1047846 \mathrm{~m}$ \\
\hline 140 & válec & 18 & 29,30 & & $\mathrm{~Pb}+\mathrm{Fe}$ & $\mathrm{X}-605295 \mathrm{~m}, \mathrm{Y}-1047762 \mathrm{~m}$ \\
\hline 141 & válec & 19 & 26,80 & & $\mathrm{~Pb}+\mathrm{Fe}$ & $\mathrm{X}-605295 \mathrm{~m}, \mathrm{Y}-1047762 \mathrm{~m}$ \\
\hline 142 & kule & 17 & 22,78 & & $\mathrm{~Pb}$ & $\mathrm{X}-605295 \mathrm{~m}, \mathrm{Y}-1047762 \mathrm{~m}$ \\
\hline 143 & válec & 17 & 41,44 & & $\mathrm{~Pb}+\mathrm{Fe}$ & $\mathrm{X}-605295 \mathrm{~m}, \mathrm{Y}-1047762 \mathrm{~m}$ \\
\hline 144 & válec & 18 & 29,76 & & $\mathrm{~Pb}+\mathrm{Fe}$ & $\mathrm{X}-605505 \mathrm{~m}, \mathrm{Y}-1047660 \mathrm{~m}$ \\
\hline 145 & kule & 18 & 30,99 & & $\mathrm{~Pb}$ & $\mathrm{X}-605308 \mathrm{~m}, \mathrm{Y}-1047635 \mathrm{~m}$ \\
\hline 147 & válec & 18 & 15,12 & & $\mathrm{~Pb}$ & $\mathrm{X}-605236 \mathrm{~m}, \mathrm{Y}-1047676 \mathrm{~m}$ \\
\hline 148 & kule & 18 & 24,82 & & $\mathrm{~Pb}$ & $\mathrm{X}-605333 \mathrm{~m}, \mathrm{Y}-1047862 \mathrm{~m}$ \\
\hline 150 & válec & 19 & 19,56 & & $\mathrm{~Pb}+\mathrm{Fe}$ & $\mathrm{X}-605324 \mathrm{~m}, \mathrm{Y}-1047636 \mathrm{~m}$ \\
\hline 152 & - & - & 44,78 & 9 & $\mathrm{~Pb}$ & - \\
\hline 154 & válec & 17 & 18,9 & 5 & $\mathrm{~Pb}$ & - \\
\hline 155 & - & - & 28,06 & & $\mathrm{~Pb}$ & $\mathrm{X}-605290 \mathrm{~m}, \mathrm{Y}-1047640 \mathrm{~m}$ \\
\hline 156 & válec & 18 & 25,57 & 8 & $\mathrm{~Pb}+\mathrm{Fe}$ & $\mathrm{X}-605289 \mathrm{~m}, \mathrm{Y}-1047639 \mathrm{~m}$ \\
\hline 158 & válec & 26 & 80,34 & 20 & $\mathrm{Fe}$ & $\mathrm{X}-605280 \mathrm{~m}, \mathrm{Y}-1047787 \mathrm{~m}$ \\
\hline 178 & válec & 18 & 20,98 & 5 & $\mathrm{~Pb}+\mathrm{Fe}$ & $\mathrm{X}-605370 \mathrm{~m}, \mathrm{Y}-1047640 \mathrm{~m}$ \\
\hline 179 & válec & 16 & 22,99 & 5 & $\mathrm{~Pb}+\mathrm{Fe}$ & $\mathrm{X}-605325 \mathrm{~m}, \mathrm{Y}-1047645 \mathrm{~m}$ \\
\hline 180 & válec & 20 & 32,24 & 10 & $\mathrm{~Pb}$ & - \\
\hline 181 & válec & 18 & 25,36 & 15 & $\mathrm{~Pb}+\mathrm{Fe}$ & $\mathrm{X}-605342 \mathrm{~m}, \mathrm{Y}-1047631 \mathrm{~m}$ \\
\hline 182 & válec & 18 & 16,98 & 5 & $\mathrm{~Pb}$ & $\mathrm{X}-605319 \mathrm{~m}, \mathrm{Y}-1047637 \mathrm{~m}$ \\
\hline 183 & válec & 22 & 38,72 & 8 & $\mathrm{~Pb}$ & $\mathrm{X}-605306 \mathrm{~m}, \mathrm{Y}-1047632 \mathrm{~m}$ \\
\hline 184 & - & - & 64,47 & 25 & $\mathrm{~Pb}$ & $X-605299 \mathrm{~m}, \mathrm{Y}-1047596 \mathrm{~m}$ \\
\hline 185 & kule & 49 & 425 & 25 & $\mathrm{~Pb}+\mathrm{Fe}$ & $\mathrm{X}-605339 \mathrm{~m}, \mathrm{Y}-1047629 \mathrm{~m}$ \\
\hline 202 & válec & 18 & 31,43 & 0 & $\mathrm{~Pb}+\mathrm{Fe}$ & $\mathrm{X}-605341 \mathrm{~m}, \mathrm{Y}-1047643 \mathrm{~m}$ \\
\hline 203 & válec & 18 & 17,28 & 12 & $\mathrm{~Pb}+\mathrm{Fe}$ & $\mathrm{X}-605205 \mathrm{~m}, \mathrm{Y}-1047489 \mathrm{~m}$ \\
\hline 205 & válec & $\mathrm{XX}$ & 23,66 & 10 & $\mathrm{~Pb}$ & $X-605244 \mathrm{~m}, \mathrm{Y}-1047573 \mathrm{~m}$ \\
\hline 206 & válec & 18 & 26,09 & 10 & $\mathrm{~Pb}+\mathrm{Fe}$ & $\mathrm{X}-605246 \mathrm{~m}, \mathrm{Y}-1047494 \mathrm{~m}$ \\
\hline
\end{tabular}




\begin{tabular}{|c|c|c|c|c|c|c|}
\hline 215 & válec & $\mathrm{XX}$ & 43,25 & & $\mathrm{~Pb}$ & $\mathrm{X}-605278 \mathrm{~m}, \mathrm{Y}-1047642 \mathrm{~m}$ \\
\hline 216 & válec & 18 & 31,42 & & $\mathrm{~Pb}+\mathrm{Fe}$ & $\mathrm{X}-605337 \mathrm{~m}, \mathrm{Y}-1047647 \mathrm{~m}$ \\
\hline 217 & válec & 18 & 34,64 & & $\mathrm{~Pb}$ & $X-605317 m, Y-1047619 m$ \\
\hline 219 & kule & 16 & 10,17 & & $\mathrm{~Pb}$ & $\mathrm{X}-605923 \mathrm{~m}, \mathrm{Y}-1041672 \mathrm{~m}$ \\
\hline 220 & válec & $\mathrm{XX}$ & 22,76 & & $\mathrm{~Pb}$ & $\mathrm{X}-605336 \mathrm{~m}, \mathrm{Y}-1047632 \mathrm{~m}$ \\
\hline 221 & válec & 19 & 27,75 & 10 & $\mathrm{~Pb}+\mathrm{Fe}$ & $\mathrm{X}-605091 \mathrm{~m}, \mathrm{Y}-1047382 \mathrm{~m}$ \\
\hline 222 & kule & 19 & 34,80 & 6 & $\mathrm{~Pb}$ & $\mathrm{X}-605200 \mathrm{~m}, \mathrm{Y}-1047378 \mathrm{~m}$ \\
\hline 223 & válec & 20 & 33,99 & 20 & $\mathrm{~Pb}+\mathrm{Fe}$ & $\mathrm{X}-605229 \mathrm{~m}, \mathrm{Y}-1047387 \mathrm{~m}$ \\
\hline 227 & válec & 17 & 33,92 & 11 & $\mathrm{~Pb}$ & $\mathrm{X}-605237 \mathrm{~m}, \mathrm{Y}-1047386 \mathrm{~m}$ \\
\hline 230 & kule & 25 & 57,79 & 20 & $\mathrm{~Pb}$ & $\mathrm{X}-605902 \mathrm{~m}, \mathrm{Y}-1041736 \mathrm{~m}$ \\
\hline 233 & kule & 21 & 57,58 & 22 & $\mathrm{~Pb}$ & $\mathrm{X}-605910 \mathrm{~m}, \mathrm{Y}-1041737 \mathrm{~m}$ \\
\hline 236 & kule & 18 & 19,31 & 15 & $\mathrm{~Pb}$ & $\mathrm{X}-605914 \mathrm{~m}, \mathrm{Y}-1041601 \mathrm{~m}$ \\
\hline 240 & válec & 17 & 25,10 & 0 & $\mathrm{~Pb}+\mathrm{Fe}$ & $\mathrm{X}-605295 \mathrm{~m}, \mathrm{Y}-1047633 \mathrm{~m}$ \\
\hline 241 & válec & 17 & 24,21 & 5 & $\mathrm{~Pb}$ & $X-605293 \mathrm{~m}, \mathrm{Y}-1047649 \mathrm{~m}$ \\
\hline 242 & válec & 17 & 22,55 & & $\mathrm{~Pb}+\mathrm{Fe}$ & $\mathrm{X}-605317 \mathrm{~m}, \mathrm{Y}-1047625 \mathrm{~m}$ \\
\hline 243 & válec & 17 & 29,57 & & $\mathrm{~Pb}+\mathrm{Fe}$ & $\mathrm{X}-605703 \mathrm{~m}, \mathrm{Y}-1047579 \mathrm{~m}$ \\
\hline 245 & válec & 22 & 16,13 & 10 & $\mathrm{~Pb}$ & $X-605306 \mathrm{~m}, \mathrm{Y}-1047599 \mathrm{~m}$ \\
\hline 246 & válec & 17 & 18,69 & 0 & $\mathrm{~Pb}+\mathrm{Fe}$ & $\mathrm{X}-605358 \mathrm{~m}, \mathrm{Y}-1047641 \mathrm{~m}$ \\
\hline 247 & válec & 16 & 26,33 & 11 & $\mathrm{~Pb}+\mathrm{Fe}$ & $\mathrm{X}-605232 \mathrm{~m}, \mathrm{Y}-1047382 \mathrm{~m}$ \\
\hline 248 & - & - & 18,27 & 25 & $\mathrm{~Pb}$ & - \\
\hline 249 & kule & 17 & 27,84 & 10 & $\mathrm{~Pb}$ & $\mathrm{X}-605377 \mathrm{~m}, \mathrm{Y}-1047670 \mathrm{~m}$ \\
\hline 250 & kule & 17 & 29,80 & 10 & $\mathrm{~Pb}$ & $\mathrm{X}-605374 \mathrm{~m}, \mathrm{Y}-1047668 \mathrm{~m}$ \\
\hline 251 & válec & 17 & 23,85 & 5 & $\mathrm{~Pb}$ & $X-605294 \mathrm{~m}, \mathrm{Y}-1047569 \mathrm{~m}$ \\
\hline 252 & kule & 18 & 24,31 & 15 & $\mathrm{~Pb}$ & $\mathrm{X}-605120 \mathrm{~m}, \mathrm{Y}-1047562 \mathrm{~m}$ \\
\hline 253 & válec & 17 & 35,52 & 22 & $\mathrm{~Pb}+\mathrm{Fe}$ & $\mathrm{X}-605402 \mathrm{~m}, \mathrm{Y}-1047672 \mathrm{~m}$ \\
\hline 254 & válec & 19 & 25,32 & 25 & $\mathrm{~Pb}+\mathrm{Fe}$ & $\mathrm{X}-605324 \mathrm{~m}, \mathrm{Y}-1047639 \mathrm{~m}$ \\
\hline 255 & - & - & 32,54 & 8 & $\mathrm{~Pb}$ & $\mathrm{X}-605219 \mathrm{~m}, \mathrm{Y}-1047385 \mathrm{~m}$ \\
\hline 256 & válec & 17 & 31,04 & 15 & $\mathrm{~Pb}$ & $\mathrm{X}-605272 \mathrm{~m}, \mathrm{Y}-1047567 \mathrm{~m}$ \\
\hline 257 & válec & 17 & 31,36 & 15 & $\mathrm{~Pb}$ & $\mathrm{X}-605348 \mathrm{~m}, \mathrm{Y}-1047622 \mathrm{~m}$ \\
\hline 258 & kule & 17 & 36,22 & 20 & $\mathrm{~Pb}+\mathrm{Fe}$ & $\mathrm{X}-605346 \mathrm{~m}, \mathrm{Y}-1047635 \mathrm{~m}$ \\
\hline 259 & válec & 18 & 20,93 & 12 & $\mathrm{~Pb}$ & $\mathrm{X}-605270 \mathrm{~m}, \mathrm{Y}-1047568 \mathrm{~m}$ \\
\hline 260 & válec & 18 & 25,85 & 20 & $\mathrm{~Pb}+\mathrm{Fe}$ & $\mathrm{X}-605357 \mathrm{~m}, \mathrm{Y}-1047642 \mathrm{~m}$ \\
\hline 261 & válec & 18 & 28,76 & 8 & $\mathrm{~Pb}+\mathrm{Fe}$ & $\mathrm{X}-605382 \mathrm{~m}, \mathrm{Y}-1047646 \mathrm{~m}$ \\
\hline 262 & válec & 18 & 26,20 & & $\mathrm{~Pb}+\mathrm{Fe}$ & $X-605399 \mathrm{~m}, \mathrm{Y}-1047667 \mathrm{~m}$ \\
\hline 269 & kule & $\mathrm{XX}$ & 431,28 & 20 & $\mathrm{~Pb}+\mathrm{Fe}$ & $\mathrm{X}-605314 \mathrm{~m}, \mathrm{Y}-1047633 \mathrm{~m}$ \\
\hline
\end{tabular}

válek je možné $40 \mathrm{ks}$ zařadit do velikostní kategorie $16-24 \mathrm{~mm}$. Z 34 projektilů pocházejících z okolí hradu Mokřice u Jičína lze celkem 19 ks zařadit do velikostní kategorie 16-20 mm (Drnovský 2021). Podobně J. Mazáčková (2012, 381, graf 35) při výčtu dostupných nálezů shledává jako nejčastěji nalézané průměry projektilů v rozmezí hodnot $17-20 \mathrm{~mm}$.

Z technologického hlediska bylo na výrobu projektilů použito olova a železa. Pouze z olova bylo odlito jedenáct kulovitých a 23 válcovitých projektilů. Poměrně vysokým počtem jsou v souboru zastoupeny tzv. kompozitní projektily. Ve třech př́ípadech byly zjištěny u kulovitých projektilů a celkem u 32 jedinců s válcovým tělem. Tyto kompozitní střely mají jádro 

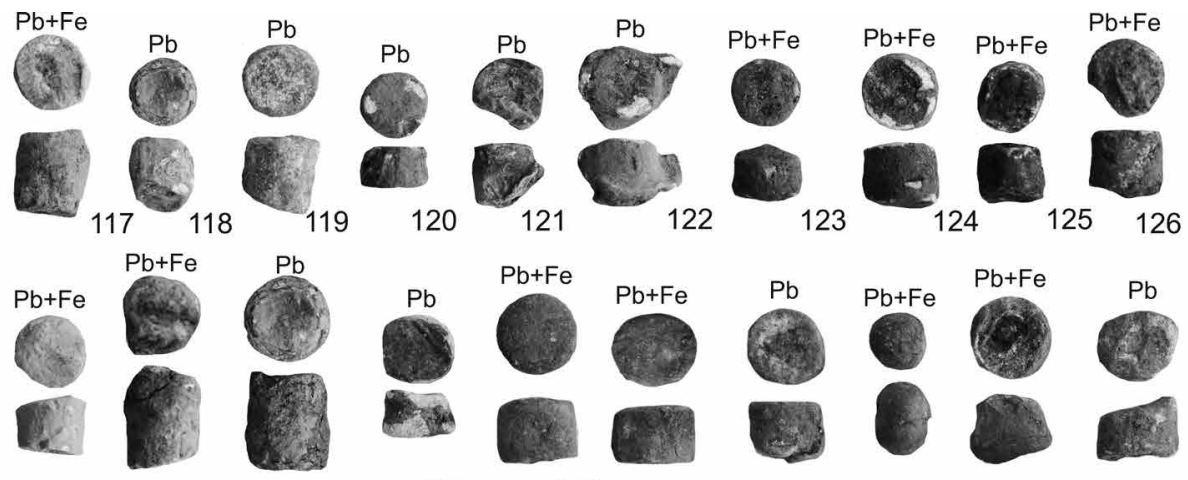

$\begin{array}{lll}127 & 128 & 138\end{array}$

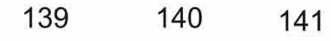

$142 \quad 143$

144

147
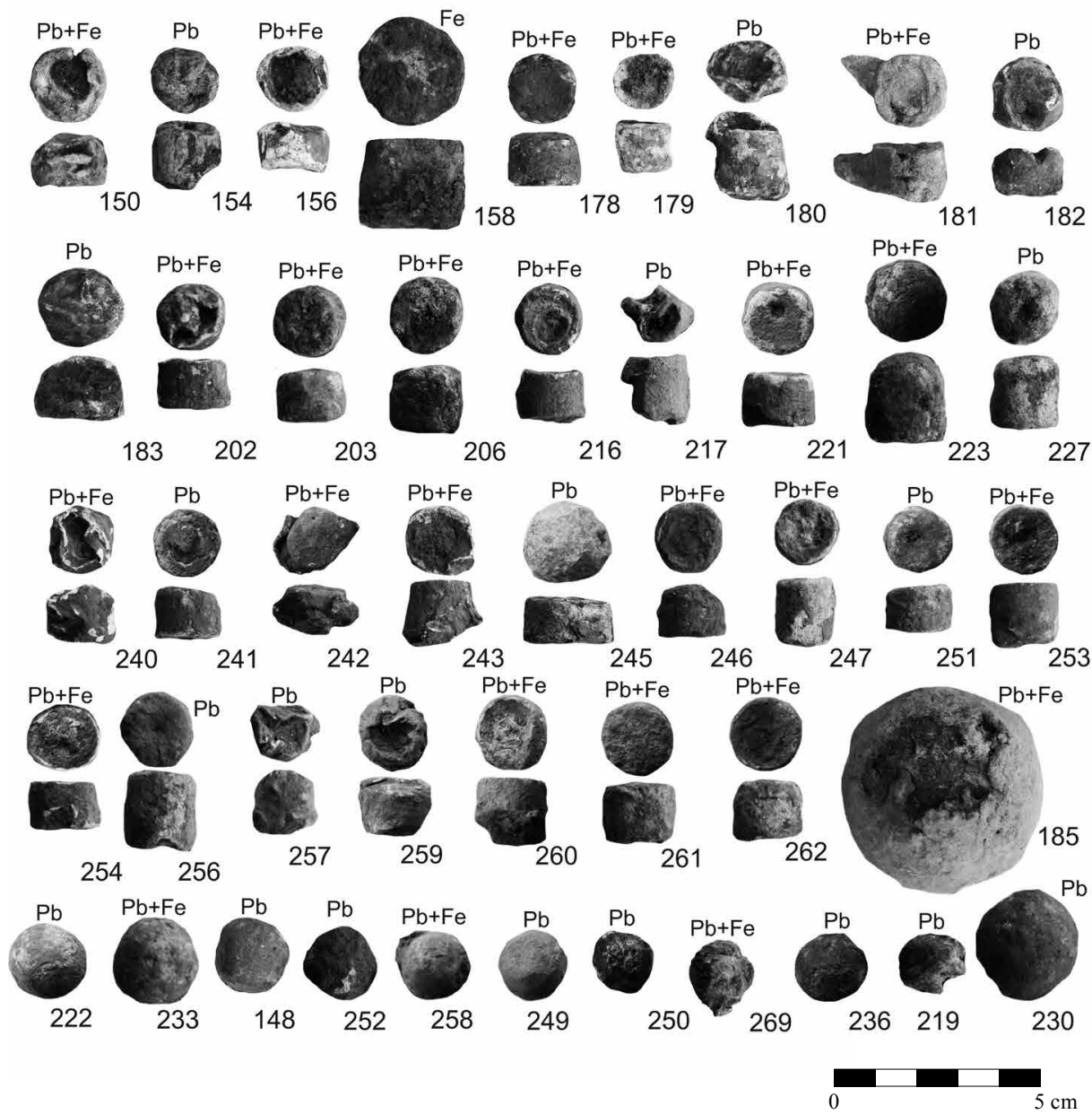

Obr. 9. Hrad Rychmberk. Projektily palných zbraní. Čísla odpovídají označení nálezů v textu.

Abb. 9. Burg Rychmberk. Feuerwaffenprojektile. Die Nummern entsprechen der Kennzeichnung der Funde im Text. 
tvořené z výkovku železa, který je obalen olovem. V české odborné literatuře se těmto typům projektilů prvně dostalo pozornosti při analýze nálezů pocházejících z obléhání hradu Sionu roku 1437 (Koscelník-Kypta-Savková 2013, 593-594). Správně bylo upozorněno na výhody plynoucí z užití složené stř̌ely, které tkví v lepším průchodu hlavní, zvýšení průraznosti projektilů a také zmenšení celkové váhy. V dobových písemných pramenech se sice vyskytují zmínky o obalování kovových střel olovem (Durdík 1954, 69; Šimůnek 2002, 245-250, Strzyż 2011, 70-71), přesto není doposud analyzováno, nakolik se jednalo o běžný postup. Určitým metodickým problémem může být, že pokud není při laboratorním zpracování použit magnet na detekci železného jádra, nelze tento typ makroskopicky poznat. Výjimku tvoří pouze natržené kompozitní střely, u kterých lze případně pozorovat užití železného jádra. Z publikovaných lokalit evidujeme v Čechách užití těchto projektilů kromě zmíněného Sionu $(17 \mathrm{ks})$ ještě z okolí hradu Červené Hory dobývaného v letech 1421 a 1427 v počtu osmi jistých exemplářů (Drnovský 2018, 162-163) a hradu Mokřice, zde ve třech prrípadech (Drnovský 2021).

Co do počtu projektilů lze soubor $\mathrm{z}$ Rychmberka zařadit $\mathrm{v}$ kontextu ostatních českých lokalit 15. století mezi ty nejpočetnější. Porovnatelné kolekce pochází pouze z hradu Sionu, Červené Hory, Lopaty či Lichnice (Drnovský 2018, 162-163; Frolík 2002; Frolík-Musil 2013; KoscelníkKypta-Savková 2013, 589-593; Novobilský 2008, 84-86).

\subsection{Ostatní militaria}

Další militaria jsou zastoupena pouze několika nálezy. Jedná se o zlomky třmenových nášlapců, záštitné trny tesáků a jednu ostruhu (tab. 4). Jako součást kuše lze označit dva fragmenty třmenových nášlapců (obr. 10). Z prvního exempláře ( $\mathrm{R} 16)$ se dochovalo rameno oválného průřezu. Na horní straně je rameno rozšířeno rozklepáním do plošky, která umožňovala spojení se sochou kuše. Většina této plošky je však vlivem koroze odlámána. Torzovitě se dochovala i spodní část třmenu, kde rameno rozšířením přechází ve stupadlo. Stupadlo bylo zesíleno na své spodní ploše třemi vystupujícími žebry. Druhý třmenový nášlapec (R 1) je tvořen horní obdélnou ploškou, ze které vybíhají fragmenty ramen s oválným průřezem. V kontextu středověkých fortifikací třmenové nášlapce samostř́li̊ představují sice ojedinělý, avšak ne zcela výjimečný nález. Neobvyklé je použití tři zesilujících žeber, nebot' spodní část stupadel bývá zpravidla opatřena pouze jedním středovým žebrem. Z východočeského prostředí lze jmenovat třmeny z hradů Brandýsa nad Orlicí (Vích 2014, 147, obr. 2:7), Červené Hory (Drnovský 2018, 161, obr. 211:8), Rotemberku (Drnovský 2018, 180, obr. 221:16), Vízmburku (Mazáčková 2013, 167, tab. 74:8) a obléhacího tábora u hradu Lichnice (Frolík-Musil 2013, 167).

Kompletně dochovanými záštitnými trny jsou na lokalitě doloženy též tesáky (R 292, 293). V obou př́padech se jedná o trny, které se vyznačují srdcovitým tvarem těla (obr. 10). Oba trny mají podobné metrické hodnoty: první je dlouhý $46 \mathrm{~mm}$ (z toho $15 \mathrm{~mm}$ krček), druhý $42 \mathrm{~mm}$ (z toho $14 \mathrm{~mm}$ krček). Dle typologie P. Žákovského se v obou prŕpadech jedná o typ t11, který je běžný spíše u krátkých tesáků (Žákovský 2014, 446-447, obr. 8:48; obr. 9:48). Jejich bližší

Tab. 4. Ostatní militaria. Metrické a nálezové vlastnosti.

Tab. 4. Sonstige Militaria. Metrische und Fundeigenschaften.

\begin{tabular}{|c|c|c|c|c|c|}
\hline číslo nálezu & nález & ev. číslo & váha $(\mathrm{g})$ & hloubka $(\mathrm{cm})$ & JTSK \\
\hline 292 & trn tesáku & 200 & 14,18 & & $\mathrm{X}-605336, \mathrm{Y}-1047632$ \\
\hline 16 & třmen kuše & $\mathrm{A} 355 / 2014$ & 52,31 & 30 & $\mathrm{X}-605310, \mathrm{Y}-1047771$ \\
\hline 5 & ostruha & $\mathrm{A} 40 / 2014$ & 2,7 & 5 & $\mathrm{X}-605264, \mathrm{Y}-1077722$ \\
\hline 1 & třmen kuše & $\mathrm{A} 486$ & 36,71 & 7 & $\mathrm{X}-605301, \mathrm{Y}-1047723$ \\
\hline 293 & trn tesáku & A 863 & 16,06 & 8 & $\mathrm{X}-605304, \mathrm{Y}-1047787$ \\
\hline
\end{tabular}



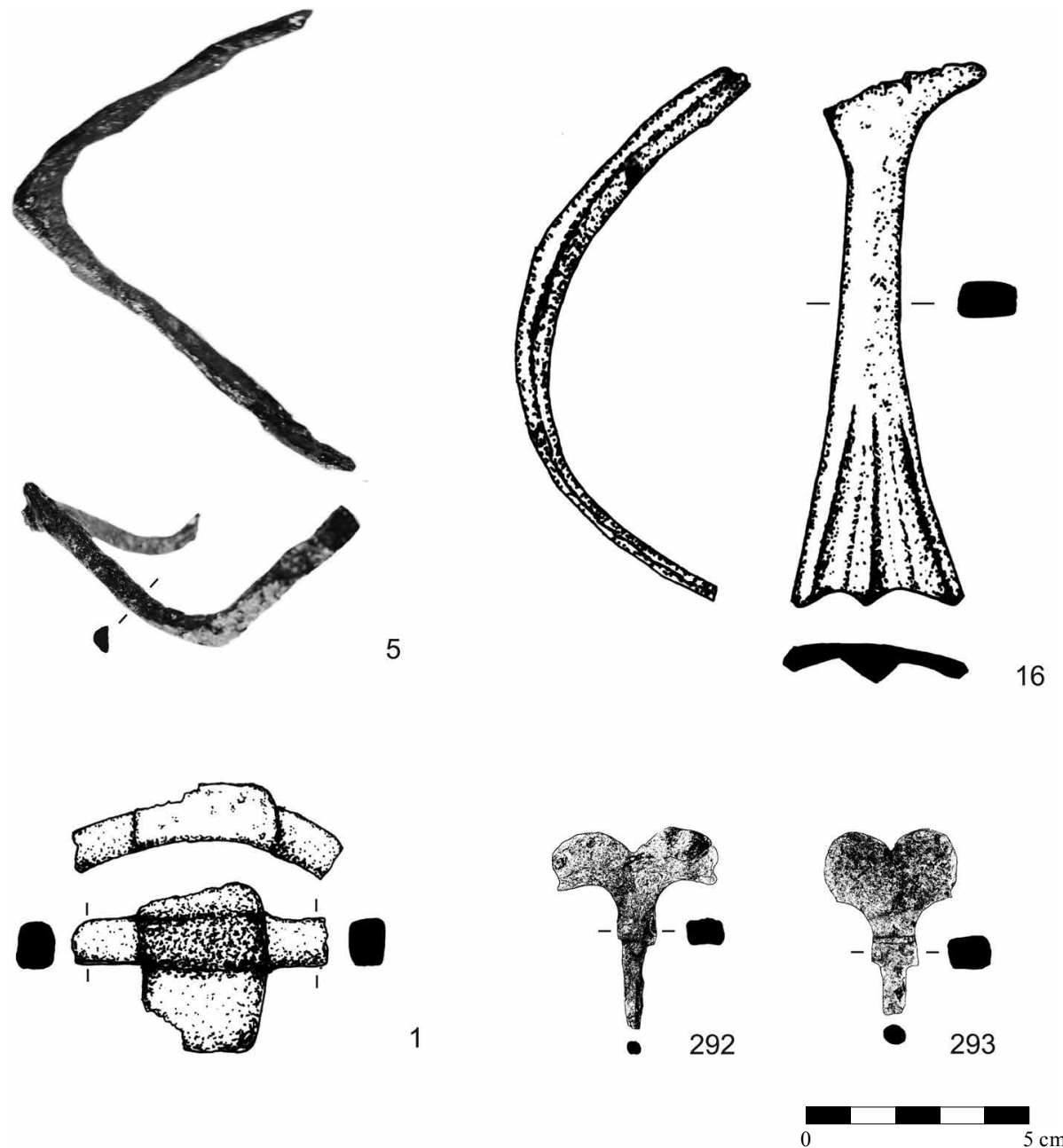

Obr. 10. Hrad Rychmberk. Ostatní militaria. Ostruha, nášlapné třmeny samostř́ílu a záštitné trny tesákủ. Čísla odpovídají označení nálezů v textu.

Abb. 10. Burg Rychmberk. Sonstige Militaria. Sporn, Steigbügel von Armbrüsten und Parierhaken von Jagdmessern. Die Nummern entsprechen der Kennzeichnung der Funde im Text.

chronologické ukotvení však není možné. Z východních Čech evidujeme doklady těchto typů záštitných trnů z hradů Orlíka u Brandýsa nad Orlicí (Vích-Žákovský 2016, 290, obr. 33:7, 41) a Vízmburku (Mazáčková 2013, 169, tab. 73:4).

Závěrem je možno uvést nález ostruhy představující součást výbavy jezdce (obr. 10). $\mathrm{Z}$ exempláře ( $\mathrm{R}$ 5) se dochovala pouze ramena bez úchytů a krčku. Ramena mají obdélný průřrez a jsou prohnutá do ostrého úhlu, jejich spojnice vytváŕí lomený oblouk. Dle třídění R. Krajíce $(2003,120)$ by bylo možno tvar ramen určit jako typ IVc/4. Ostruha by patrně mohla, s jistou mírou zdrženlivosti z důvodu absence úchytů a krčku, odpovídat ostruhám tvarové varianty $\mathrm{C}$ podle S. Kołodziejského $(1985,166)$. Obecně se jedná o velmi častý typ ostruh, jejichž těžiště výskytu bývá kladeno do průběhu 13. až počátku 15. století (Koóšová 2004, 533-536). 


\section{Možnosti interpretace nálezového souboru}

Stavebník hradu vybral pro Rychmberk polohu, která je typická i pro jiné fortifikace založené na přelomu 13. a 14. století v podhůřri Orlických hor. Jednalo se o ze tří stran přírodně chráněnou polohu, která však byla ze čtvrté strany, od východu, volně př́stupná. Tomu odpovídá i násobení obrany hradu na tomto úseku v podobě př́íných valů a příkopů. Tyto útvary nemusí pochopitelně pocházet ze stejné stavební fáze a mohou odrážet události 15 . století, kdy byl hrad nejméně třikrát dobýván.

Mezi hlavní strategické nevýhody polohy Rychmberka patř́i umístění hradní ostrožny mezi dva převyšující protilehlé svahy. Jak severní, tak jižní protilehlý svah převyšují polohu hradního jádra o zhruba 10 metrů. Výška hradních budov sice mohla tuto nevýhodu mírnit, přesto v neprospěch obránců hrála další skutečnost, a to že oba svahy jsou od hradního jádra vzdáleny přibližně pouhých 160 (severní) a 110 metrů (jižní).

Díky zaznamenávání polohy jednotlivých kovových nálezů během detektorové prospekce můžeme pracovat s více než 260 body. Při základním vynesení všech militarií bez podrobnějšího třídění se nám naskytne pohled na distribuci nálezů ve vztahu k Rychmberku. Nálezy jsou přítomny na obou svazích hradního kopce, koncentrují se i na obou protilehlých svazích a větší počty se táhnou i severním směrem po údolí Liberského potoka. Většina nálezů pochází ze vzdálenosti menší než 180 metrů od jádra hradu (obr. 11).

Na základě distribuce nálezů lze s určitou dávkou nejistoty rozdělit militaria na munici vystřelenou proti hradu a na munici vystřelenou obránci. Za nálezy spojené s útočníky lze považovat artefakty nalezené v samé blízkosti Rychmberka a na přilehlých svazích hradního kopce. Naopak

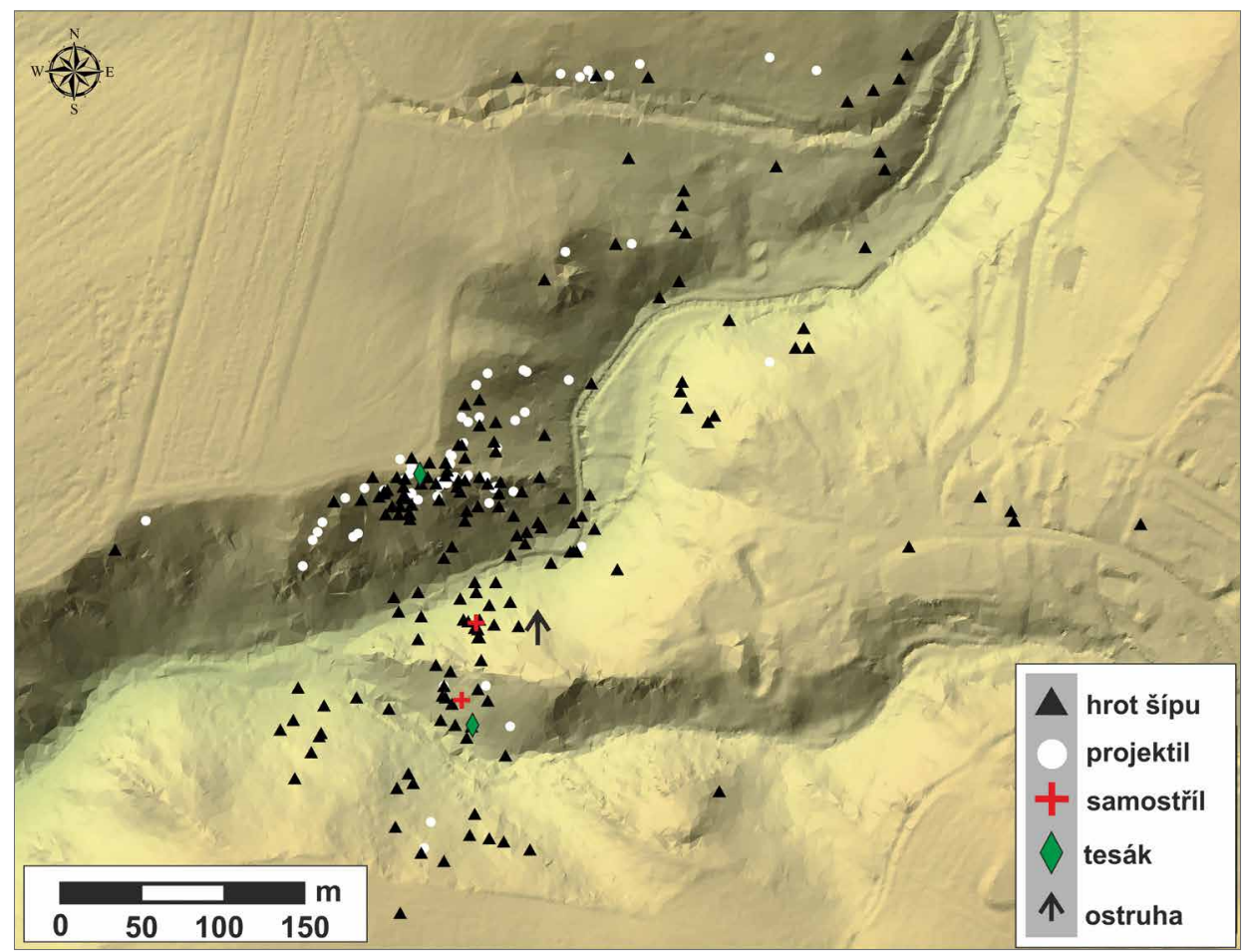

Obr. 11. Poloha jednotlivých skupin nálezů. Černý trojúhelník - hrot šípu, bílý kruh - projektil, kříž - samostř́l, kosočtverec - tesák, šipka - ostruha. Na základě podkladů P. Drnovského vytvořil M. Lanta.

Abb. 11. Lage der jeweiligen Fundgruppen. Schwarzes Dreieck - Pfeilspitze, weißer Kreis - Projektil, Kreuz - Armbrust, Raute - Jagdmesser, Pfeil - Sporn. Nach P. Drnovskýs Unterlagen erstellt von M. Lanta. 
nálezy objevené mimo hradní ostrožnu (zejména protilehlé svahy) považujeme za střelivo použité obránci hradu proti dobyvatelům. Většina munice, získané díky nálezům, tak byla vystřelena z hradu proti útočníkům. Je ale nutno mít na paměti, že vlastní hradní jádro, včetně úpatí hradeb, je naprosto zásadně postiženo destrukcí a následnými sesuny. Nepřekvapí, že hlavní koncentrace se nachází na obou protilehlých svazích, a to $\mathrm{v}$ místech, která jsou nejblíže k jádru hradu (ca 100-170 metrů). Munice obránců se nachází až do vzdálenosti 350 metrů od hradu, a to severním směrem na svazích s pomístními názvy Brusina a Městský.

Hroty šípů, jakožto nejvíce zastoupený druh militarií, jsou přítomny ve všech koncentracích nálezů a ve všech polohách. Hroty nasazované na střeliště šípu pomocí trnu jsou zastoupeny jak na hradní ostrožně, tak v okolních polohách, z čehož plyne, že byly použity jak obránci, tak útočníky. Stejná situace panuje u hrotů šípů opatřených tulejí. Jedinci výše zmíněné skupiny hrotů šípů s rombickým průřezem a zúženým tělem na přechodu $\mathrm{k}$ tuleji se nachází pouze $\mathrm{v}$ polohách, které nasvědčují vystřelení z pozic obránců hradu (obr. 12).

Většina nalezených projektilů z palných zbraní byla rovněž vystřelena obránci. V areálu hradu se našlo pouze pět válcovitých projektilů. Obránci tak disponovali municí tvořenou jak olovem, tak i kompozitními projektily s železným jádrem a olovněným obalem. Rovněž největší zastoupený projektil ráže 49 mm (R 185) byl vystřelen obránci do severního protilehlého svahu (obr. 13).

Oba nalezené třmenové nášlapce samostřílů patrně patřily hradní posádce. Byly sice nalezeny zhruba v polovině svahů hradní ostrožny, sem se však zřejmě dostaly v rámci depozičních procesů (obr. 13). Spojovat oba nálezy s útokem dobyvatelů přes nejvíce neschůdný př́ístup $\mathrm{k}$ hradu se jeví jako málo pravděpodobné. Zatímco první záštitný trn (R 292) lze vzhledem k místu nálezu

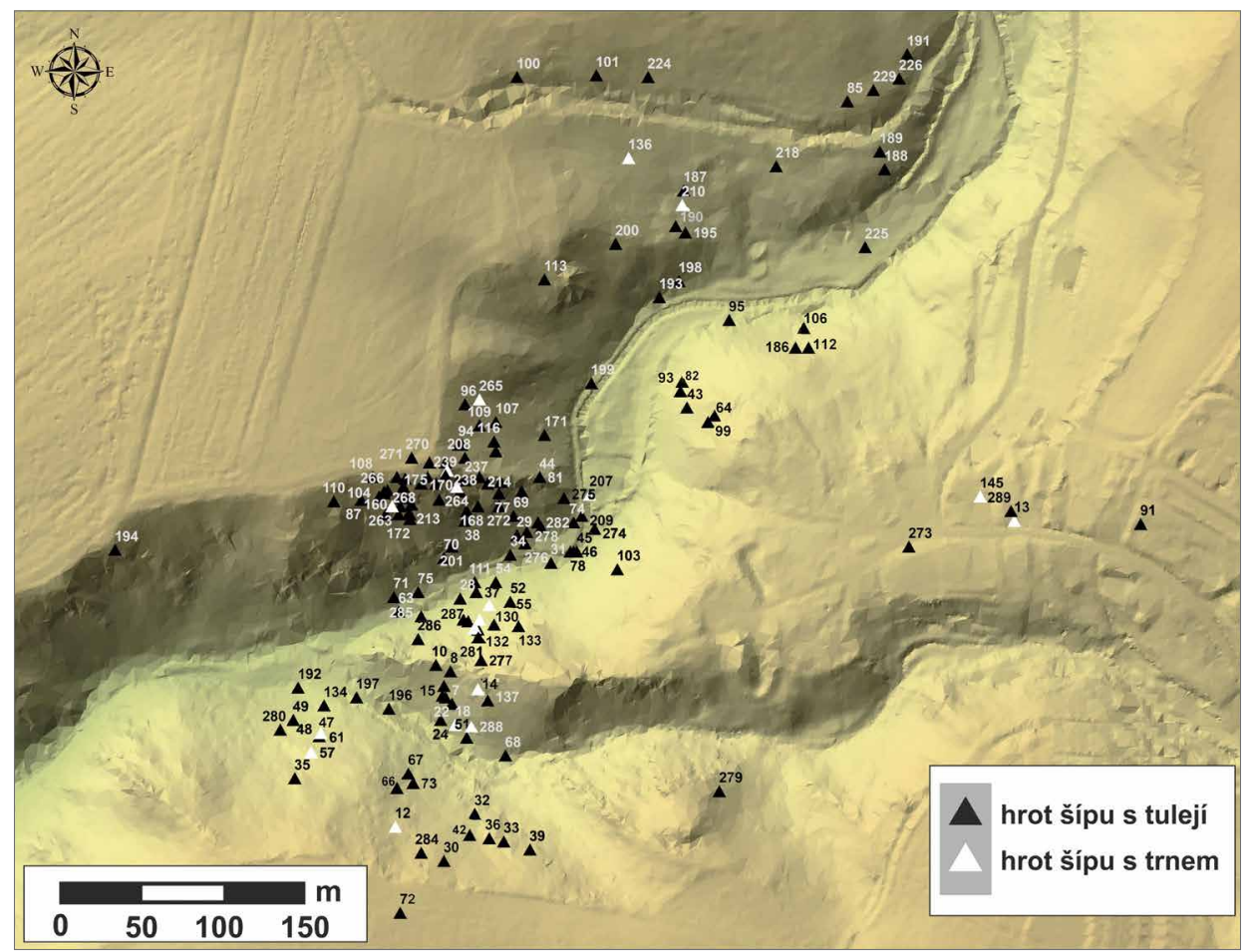

Obr. 12. Rozložení hrotů šípů. Černý trojúhelník - hrot šípu s tulejí, bílý trojúhelník - hrot šípu s trnem. Čísla odpovídají označení nálezů v textu. Na základě podkladů P. Drnovského vytvořil M. Lanta.

Abb. 12. Verteilung der Pfeilspitzen. Schwarzes Dreieck - Pfeilspitze mit Tülle, weißes Dreieck - Pfeilspitze mit Dorn. Die Nummern entsprechen der Kennzeichnung der Funde im Text. Nach P. Drnovskýs Unterlagen erstellt von M. Lanta. 
na severním protilehlém svahu spojit s útočníky, nález druhého záštitného trnu (R 293) na jižním úpatí hradní ostrožny již takové spojení neumožňuje. Ostruha (R 5) objevená poblíž hradního jádra pak nejspíše souvisí s běžným provozem spojeným s existencí sídla.

Vzájemně odlišit nalezené artefakty dle historických událostí 15 . století, kdy víme, že byl hrad obléhán a dobyt, dokážeme jen stěží. Nedostatečná chronologická citlivost jednotlivých artefaktů jednoznačné časové odlišení neumožňuje. Všechny typy jsou totiž v rámci míst spojených s konflikty 15. století běžně nacházeny. Snad pouze hroty šípů opatřené trnem by mohly spíše odpovídat prvnímu známému dobývání hradu roku 1425. Jejich použití př̀i posledním doloženém obležení v roce 1457 je již málo pravděpodobné. Užití kompozitních střel je u východočeského hradu Červené Hory doloženo nejpozději k roku 1427. Tedy ani v př́ípadě rychmberských nálezů nelze vyloučit užití této munice již během prvního známého dobývání roku 1425.

Při pohledu na mapu distribuce militarií tak v podsadě zaznamenáváme obraz minimálně tří úspěšných vojenských akcí proti hradu. Přestože nejsme schopni rozlišit jednotlivé artefakty podle obležení zaznamenaných v písemných pramenech, na základě koncentrace nálezů alespoň můžeme naznačit tendence ve strategii útočníků. Poloha hradu umožnila dobyvatelům dosažení pozic, ze kterých bylo možné Rychmberk ostřelovat na poměrně krátkou vzdálenost (obr. 14). Tomu odpovídají i koncentrace hrotů šípů a projektilů na severním a jižním protilehlém svahu. Z jejich výskytu zde je jednak možno usuzovat na přítomnost útočníků v těchto místech a na snahu obránců zamezit, či spíše omezit jejich aktivity. Obléhatelé hradu patrně zaujali i vzdálenější pozice severně

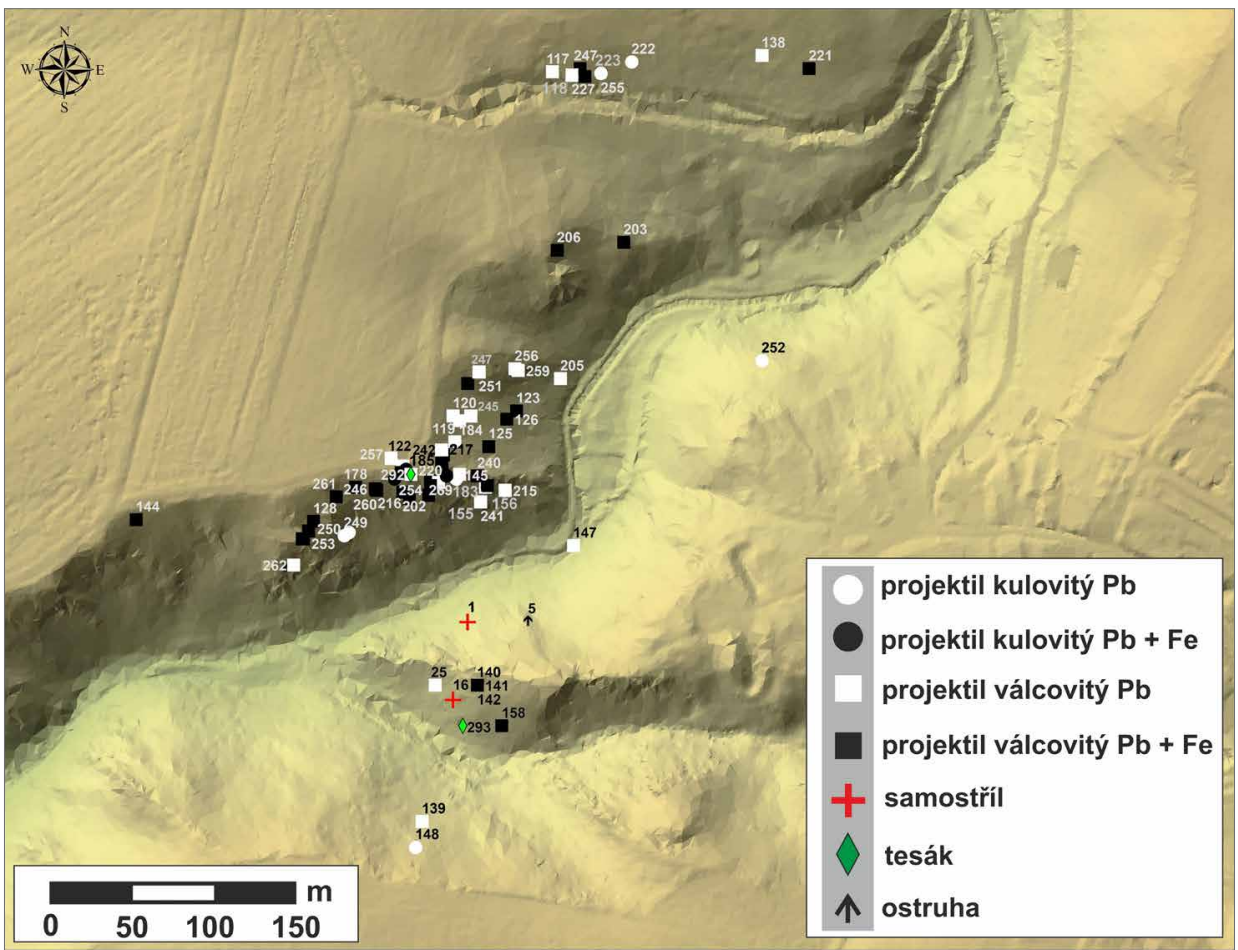

Obr. 13. Rozložení projektilů a ostatních militarií. Bílý kruh - projektil kulovitý (Pb), černý kruh - projektil kulovitý $(\mathrm{Pb}+\mathrm{Fe})$, bílý čtverec - projektil válcovitý $(\mathrm{Pb})$, černý čtverec - projektil válcovitý $(\mathrm{Pb}+\mathrm{Fe})$, kříž - samostříl, kosočtverec - tesák, šipka - ostruha. Čísla odpovídají označení nálezů v textu. Na základě podkladů P. Drnovského vytvořil M. Lanta.

Abb. 13. Verteilung der Projektile und sonstiger Militaria. Weißer Kreis - kugelförmiges Projektil (Pb), schwarzer Kreis kugelförmiges Projektil (Pb + Fe), weißes Quadrat - zylinderförmiges Projektil (Pb), schwarzes Quadrat - zylinderförmiges Projektil $(P b+$ Fe), Kreuz - Armbrust, Raute - Jagdmesser, Pfeil - Sporn. Die Nummern entsprechen der Kennzeichnung der Funde im Text. Nach P. Drnovskýs Unterlagen erstellt von M. Lanta. 
od hradu, jak opět dokládají militaria spojená s obránci hradu na svazích s pomístními názvy Brusina a Městský. Jestliže ovšem chtěli útočníci dosáhnout samotného jádra hradu, a nespokojili se pouze $\mathrm{s}$ jeho ostřelováním, museli se přiblížit po jediném schůdném př́ístupu, který vedl od východu přes zástavbu městečka přecházející $\mathrm{k}$ předpolí hradu a opevněnému předhradí. Útok, či postup přes strmé skalnaté srázy hradní ostrožny se zdá jako méně pravděpodobný. Bohužel území východně od hradu je dnes zastavěno a neumožňuje tak plně rozvinout archeologickou prospekci. Přesto i z těchto míst pochází čtyři hroty šípů, které dokládají, že útok byl veden i tímto směrem.

Většina nálezů vzešlých z detektorové prospekce pochází z míst mimo hradní ostrožnu. Důvodů, proč z hradního areálu a jeho okolí pochází pouze menší část souboru, může být více. Jednak je nutné počítat s dřívějšími nelegálními prospekcemi, a tedy zmizením části nálezového spektra. Opomenout nelze ani možnost, že se část nálezů stále nachází v destrukčních vrstvách hradu, př́ípadně se s nimi sesunula ze svahu. Vzhledem k tomu, že Rychmberk byl přes dvě obléhání v letech 1425 a 1441 stále obýván (neznáme míru poškození hradu), je pravděpodobné, že viditelné hroty šípů a projektily nacházející se $\mathrm{v}$ areálu hradu a jeho blízkosti mohly být jednoduše posbírány již v době provozu sídla.

Na vojenský stř̌et upomínají i tři pomístní názvy lokalit ležících jižně od hradu: Na Bojišti, Bojiště a $K$ baště. Tato toponyma označují místa, která nejsou s hradem v přímém vizuálním kontaktu a jsou i poměrně dosti vzdálena, než aby odkazovala na místa bojů (450-700 metrů). Pokud tak nedošlo k posunutí toponym během historického vývoje, mohla by snad reflektovat umístění některého z táborů útočníků. V případě pomístního názvu $K$ baště by se mohlo jednat bud' o palebné postavení dobyvatelů, či o památku na předsunutou fortifikaci náležející $\mathrm{k}$ hradu.

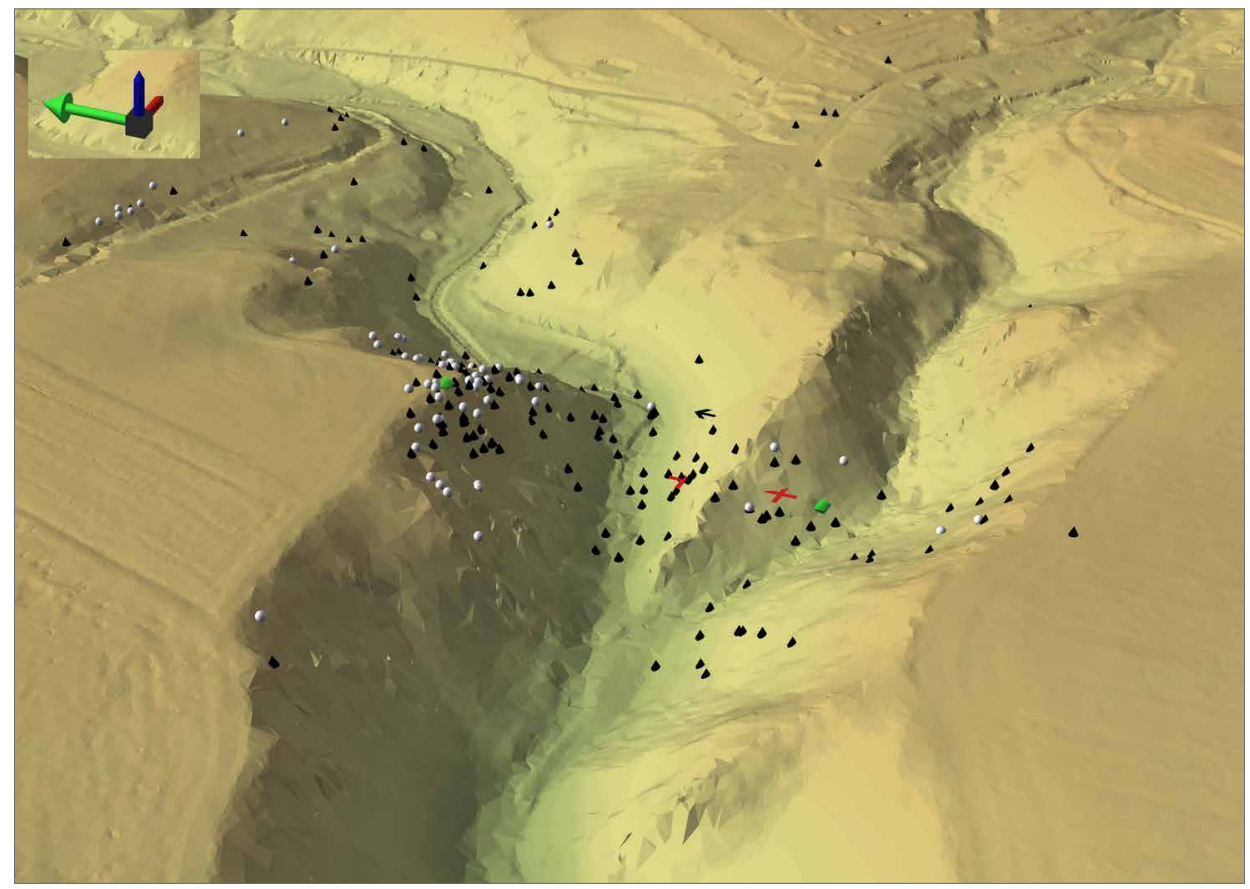

Obr. 14. Perspektivní pohled na hradní ostrožnu a její okolí. Zaznamenána poloha základních skupin nálezů. Trojúhelník hrot šípu, bílý kruh - projektil, kříž - samostříl, kosočtverec - tesák, šipka - ostruha. Na základě podkladủ P. Drnovského vytvořil M. Lanta.

Abb. 14. Perspektivische Ansicht des Burgfelssporns und seiner Umgebung. Eingezeichnete Lage der Fundgruppen. DreieckPfeilspitze, weißer Kreis - Projektil, Kreuz - Armbrust, Raute - Jagdmesser, Pfeil - Sporn. Nach P. Drnovskýs Unterlagen erstellt von M. Lanta 
Co do počtu nalezených militarií, která lze spojit s obléháním hradu (zejména hroty šípů, projektily palných zbraní), patří kolekce z Rychmberka mezi ty nejpočetnější v kontextu středoevropského prostoru. Srovnatelné jsou pouze rovněž objemné soubory z hradů Mokřice (Drnovský 2021) a Zítkova u Chocně (Vích 2017). Z dalších již méně početných souborů je možno uvést ještě nálezy z hradu Božanova (Drnovský-Mazáčková-Šrámek 2019), Lopaty (Novobilský 2008) a Sionu (Koscelník-Kypta-Savková 2013). V případě Rychmberka však vynikne zejména skutečnost, že detektorový průzkum pokryl nejen prostor hradní ostrožny, ale i vzdálenější polohy v okolí hradu.

\section{Závěr}

V současné době přibývá kolekcí vzešlých z detektorového průzkumu středověkých fortifikací, které byly odevzdány do prŕśslušných muzeí. Bohužel však u nich často postrádáme potřebné nálezové informace. Soubor pocházející z hradu Rychmberka a jeho okolí pochází z detektorové prospekce organizované rychnovských muzeem. Díky prostorovým datům bylo možné odlišit munici obránců a obléhatelů a stejně tak sledovat směry útoků na hrad. Jak útočníci, tak obránci disponovali palnými zbraněmi. Vzhledem k velikosti munice vystřelené z hradu je možné počítat s př́tomností lafetovaných palných zbraní v inventáři hradní posádky. Naopak nelze, vzhledem k charakteru nálezů, vzájemně odlišit chronologické horizonty, které by odpovídaly obležením hradu v letech 1425, 1441 a 1457, známým v písemných pramenech. Důvodem pro uskutečnění detektorového průzkumu lokality byly soustavné návštěvy detektorářů. Z takto získaných artefaktů nebylo do rychnovského muzea prozatím nic odevzdáno. Přesto provedený výzkum ukázal, že lokalita nebyla zcela vysbírána. Ukázalo se tak, že i u zdánlivě zdevastované lokality lze ještě získat reprezentativní nálezový soubor. Nicméně je zřejmé, že podstatnou část své výpovědní hodnoty již hrad Rychmberk pozbyl v nedávném období.

Př́spěvek vznikl za podpory Specifického výzkumu FF UHK 2021 Nedestruktivní formy výzkumu středověkých a novověkých fortifikací.

\section{Prameny}

AČ 1: Archiv český, čili staré písemné památky české i morawské. Díl 1 (Palacký, F., ed.). Praha 1840.

AČ 2: Archiv český, čili staré písemné památky české i morawské. Díl 2 (Palacký, F., ed.). Praha 1842.

AČ 5: Archiv český, čili staré písemné památky české i morawské. Díl 5 (Palacký, F., ed.). Praha 1862.

LC I/1: Libri confirmationum ad beneficia ecclesiastica pragensem per archidioecesim I/1 1354-1362

(Tingl, F. A., ed.). Pragae 1867.

LC I/2: Libri confirmationum ad beneficia ecclesiastica pragensem per archidioecesim I/2 1363-1369 (Emler, J., ed.). Pragae 1874 .

RBM: Regesta diplomatica nec non epistolaria Bohemiae et Moraviae. Pars II 1253-1310, (Emler, J., ed.). Praha 1882.

RT: Reliquiae tabularum terrae regni Bohemiae. Pozůstatky desk zemských království českého I (Emler, J., ed.). Praha 1870 .

\section{Literatura}

BEKOVÁ, M.-SLAVÍK, J., 2021: Předsunutá opevnění hradů pod Orlickými horami, AVČ 20, 260-271.

DRNOVSKÝ, P., 2018: Hmotná kultura šlechtických sídel severovýchodních Čech: Každodennost ve stř̌edověku pohledem archeologie. Červený Kostelec. 
- 2021: Soubor kovových nálezů z hradu Mokřice u Lužan a jeho blízkého okolí (okres Jičín) - Komplex an Metallfunden von Burg Mokřice bei Lužany und ihrer nahen Umgebung (Bezirk Jičín), AH 46, $147-171$.

DRNOVSKÝ, P.-MAZÁČKOVÁ, J.-ŠRÁMEK, J., 2019: Hrad u Božanova na Broumovsku a jeho možná úloha při stabilizaci broumovského klášterního dominia - Die Burg bei Božanov im Braunauer Ländchen und ihre mögliche Aufgabe bei der Stabilisierung des Klosterdominiums Braunau (Broumov), AH 44, 559-605. https://doi.org/10.5817/AH2019-2-4

DURDÍK, J., 1954: Husitské vojenství. Praha.

- 1983: Středověké zbraně. Sbírky okresního muzea v Chrudimi. Historická řada 2/II. Chrudim.

FROLÍK, J., 2002: Nálezy z obléhání hradu Lichnice v letech 1428-1429, CB 8, 399-408.

FROLÍK, J.-MUSIL, J., 2013: Několik poznámek k obléhání hradu Lichnice v letech 1428-1429, Chrudimský vlastivědný sborník 17, 125-214.

FRÝDA, F., 1988: Plzeňská městská zbrojnice I. Plzeň.

HEJNA, A., 1962: Soubor nálezů z Hrádku u Bolkova v severovýchodních Čechách, PA LIII, 455-471.

- 1974: Bradlo u Hostinného nad Labem. Příspěvek k výzkumu opevněných sídel v severovýchodních Čechách - Die Feste auf Bradlo bei Hostinné n. L. (Arnau an der Elbe) - ein Beitrag zur Burgenforschungen in Nordostböhmen, PA LXV, 365-418.

KOŁODZIEJSKI, S., 1985: Les éperons à molette du territoire de la Petit Pologne au Moyen Âge. In: Memoires archéologiques (Kokowski, A., ed.), 161-179. Lublin.

KOÓŠOVÁ, P., 2004: Ku klasifikácii vrcholnostredovekých ostrôh z územia Slovenska (12.-15. storočie) Zur Klassifikation der hochnmittelalterlichen Sporen auf dem Gebiet der Slowakei (12.-15. Jahrhundert), AH 29, 523-547.

KOSCELNÍK, P.-KYPTA, J.-SAVKOVÁ, J., 2013: Dobývání hradu Siónu roku 1437. Povrchový průzkum palebných postavení obléhatelů, AR LXV, 574-598.

KRAJÍC, R., 2003: Sezimovo Ústí. Archeologie středověkého poddanského města 3. Kovárna v Sezimově Ústí a analýza výrobků ze železa I, II. Praha - Sezimovo Ústí - Tábor.

KREJSOVÁ, J., 2005-2006: Nastřihnuté hroty šípů z hradu Rokštejna, SPFFBU M 10-11, 161-169.

KURKA, J., 1915: Archidiakonáty kouřimský, boleslavský, hradecký a diecése litomyšlská (místopis církevní do r. 1421). Praha.

MAZÁČKOVÁ, J., 2012: Militaria z hradu Rokštejna v širším středoevropském kontextu. Rkp. disertační práce, ulož. v ÚAM FF MU, Brno.

- 2013: Militaria. In: Vízmburk. Př́iběh ztraceného hradu (Koštál, J., ed.), 164-170. Havlovice.

MUSIL, F., 2009: Vrcholná kolonizace a východní Čechy. In: Felcman, O.-Musil, F. a kol., Dějiny východních Čech v pravěku a středověku (do roku 1526), 301-382. Praha.

MUSIL, F.-SVOBODA, L., 1998: Hrady, zámky a tvrze okresu Rychnov nad Kněžnou. Ústí nad Orlicí.

NOVOBILSKÝ, M., 2008: Obléhání hradu Lopaty. Rekonstrukce obléhání hradu z roku 1432-1433. Plzeň.

PLAČEK, M., 1991: Příspěvek k poznání hradů v podhůří Orlických hor, Sborník Společnosti přátel staroŽitností 2, 145-159.

PRIHODA, R., 1932: Zur Typologie und Chronologie mittelalterlicher Pfeilspitzen und Armbrustbolzeneisen, Sudeta 8, 43-67.

PROFOUS, A., 1949: Místní jména v Čechách, jejich vznik, původní význam a změny. Díl 1. A-H. Praha.

RUTTKAY, A., 1976: Waffen und Reiterrüstung des 9. bis zur ersten Hälfte des 14. Jahrhunderts in der Slowakei (II), SlArch XXIV, 245-395.

SEDLÁČEK, A., 1883: Hrady, zámky a tvrze království českého II, Hradecko. Praha.

SERDON, V., 2005: Armes du diable. Arcs et arbalètes au Moyen Âge. Rennes.

STRZYŻ, P., 2011: Średniowieczna broń palna w Polsce. Studium archeologiczne. Łódź.

ŠANDERA, M., 2005: Zikmundovi věrní na českém severovýchodě. Opočenská strana v husitské revoluci. České Budějovice.

- 2009: Východní Čechy jako hlavní kališnická základna v zemi. In: Felcman, O.-Musil, F. a kol., Dějiny východních Čech v pravěku a středověku (do roku 1526), 581-622. Praha.

ŠIMEK, T. a kol., 1989: Hrady, zámky a tvrze v Čechách, na Moravě a ve Slezsku. Východní Čechy VI. Praha. 
ŠIMŮNEK, R., 2002: Hradní inventář jako typ písemnosti a možnosti jeho badatelského využití. (Na př́ikladu inventáŕů rožmberských hradů ca. 1450-1470), Husitský Tábor 13, 229-253.

VÍCH, D., 2014: Kovové nálezy z hradu v Brandýse nad Orlicí, CB 14, 142-155.

- 2017: Projectile head finds from Zítkov Castle near Choceň, Acta Militaria Mediaevalia XIII, 83-109.

VÍCH, D.-ŽÁKOVSKÝ, P., 2016: Vojenské vybavení bojové družiny před husitskou revolucí. Soubor militarií z hradu Orlík u Brandýsa nad Orlicí ve východních Čechách, PA CVII, 279-351.

WOLF, V., 2002: Jan Kolda ze Žampachu. Život táborského hejtmana, loupeživého rytírée, kondotiéra a psance. Hradec Králové.

ZIMMERMANN, B., 2000: Mittelalterliche Geschossspitzen. Kulturhistorische, archäologische und archäometallurgische Untersuchengen. Schweitzer Beiträge zur Kulturgeschichte und Archäologie des Mittelalters 26. Basel.

ŽÁKOVSKÝ, P., 2014: Tesáky a problematika jednosečných zbraní středověku ar raného novověku. Rkp. disertační práce, ulož. v ÚAM FF MU, Brno.

\section{Zusammenfassung}

\section{Militaria aus der Umgebung von Burg Rychmberk in Ostböhmen als Belege für ihre Eroberung}

Die Überreste von Burg Rychmberk befinden sich am Westrand der Gemeinde Liberk in der Nähe von Rychnov nad Kněžnou (Abb. 1). Der Bauherr hatte sich für den Sitz einen schmalen Felssporn ausgesucht, der von den steilen Tälern des Baches Liberský potok im Norden und einem namenlosen Wasserlauf im Süden abgegrenzt wird (Abb. 2).

Das Adelsprädikat von Rychmberk wurde erstmals 1310 von einem Wilhelm verwendet, der womöglich auch ihr Gründer hatte sein können. Ab Ende des 14. Jahrhunderts war sie im Besitz der Herren von Častolovic (Půta I., II. und III.). Půta III. gehörte während den Hussitenkriegen zu den Verbündeten von Sigismund von Luxemburg. Aus diesem Grund wurde die Burg im Jahr 1425 von den ostböhmischen Hussiten belagert und erobert. Nach dem Tod von Půta III. (1435) nahm Jan Kolda d. J. Von Žampach die Burg ein. Im Jahr 1441 haben die ostböhmischen Landfriedensbündler eine Militärkampagne gegen ihn geführt. Die Burg wurde 1457 schießlich von König Georg von Poděbrad erobert, zerstört und den Gütern der Herrschaft Lititz einverleibt.

Die Relikte von Burg Rychmberk und ihrer Umgebung wurden wiederholt von illegalen Metalldetektorsuchen heimgesucht, weswegen die archäologische Abteilung des Museums und der Galerie des Adlergebirges in Rychnov nad Kněžnou dazu überging, eine gezielte Detektorsuche durchzuführen.

Die am häufigsten vertretene Gruppe Militaria stellen Pfeilspitzen dar. Insgesamt handelt es sich um 188 Exemplare (Tab. 2). In der Kollektion sind dann sowohl Geschossspitzen vertreten, die mit einem Dorn befestigt wurden (20 Exemplare), also auch solche, die mit Tüllen ausgestattet sind (168 Exemplare). Bei den mit einem Dorn versehenen überwiegen Exemplare mit schlanker Form des Körpers mit rautenförmigem Querschnitt (Abb. 8). In der Regel werden solche Geschossspitzen der Bogenmunition zugeordnet. Die Verfasser von diese Geschossspitzenart erwähnenden Publikationen ordnen sie dem breiten zeitlichen Rahmen vom 11. bis zum 14. Jahrhundert zu (Zimmermann 2000, 75; Serdon 2005, 124).

Unter den mit Tüllen versehenen Geschossspitzen dominieren klar zwei einander nahestehende Gruppen, für die insgesamt ihre Robustheit und ein rautenförmiger Querschnitt des Körpers charakteristisch ist (Abb. 4, 5, 6, 7). Sie unterscheiden sich lediglich in der Form ihres Körpers. Im Falle dieser Geschossspitzen herrscht allgemeine Übereinstimmung darüber, dass es sich dabei um Armbrustmunition handelt. Die Gewichtsskala der Geschossspitzen von Rychmberk entspricht dieser Schlussfolgerung. Es handelt sich um die verbreitetsten Munitionsarten, deren Vorkommensschwerpunkt vornehmlich in den Zeitraum 14.-15. Jahrhundert gelegt wird 
(Krajíc 2003, 187; Serdon 2005, 101-102; Zimmermann 2000, 47). Eine weitere Geschossspitzengruppe stellen mit Tülle versehene Exemplare und quadratischem Körperquerschnitt dar. In der Kollektion ist dies bei 17 Exemplaren der Fall (Abb. 4). Ihre Gewichtsskala entsprich den zwei vorhergehenden Typen.

Bei der Gesamtbeurteilung der Geschossspitzenkollektion überwiegen klar die Exemplare mit Tülle. Vertreten sind hier besonders solche Typen (86\%), die berechtigterweise als Armbrustmunition bezeichnet werden (Diagramm 1). Obwohl bei einigen Typen auch schon vor dem 13. Jahrhundert ein Vorkommen beobachtet werden kann, halten wir uns aufgrund der historischen Angaben eher an die Einordnung unserer Kollektion in die Zeitspanne zwischen dem 13. und 15. Jahrhundert. Für die Kollektion aus Rychmberk können wir als Analogie besonders Funde von solchen Fundstellen anführen, die mit der Zeit der Hussitenkriege und der anschließenden Poděbrader Periode zusammenhängen. Hier können besonders die Kollektionen von den Burgen Mokřice (Drnovský im Druck), Sion (Koscelník-Kypta-Savková 2013), Vízmburk (Mazáčková 2013) und Zítkov bei Choceň (Vích 2017) erwähnt werden.

Die zweite zahlreiche Fundgruppe bilden Feuerwaffenprojektile, von denen insgesamt 76 Exemplare entdeckt wurden (Tab. 3). Bei der Grundeinteilung ihrer Formen können 14 kugelförmige Projektile ausgemacht werden, und in der Kollektion dominieren 56 zylinderförmige Projektile (Abb. 9). Anhand des Durchmessers können kugelförmige und zylinderförmige Projektile nach Größenkategorieren unterteilt werden (Diagramm 2). In technologischer Hinsicht hat man Blei und Eisen für die Herstellung der Projektile verwendet. Nur aus Blei gegossen wurden 11 kugelförmige und 23 zylinderförmige Projektile. In relativ hoher Zahl sind in der Kollektion sog. Kompositprojektile vertreten. Bei den kugelförmigen Projektilen wurden sie in drei Fällen und bei insgesamt 32 Exemplaren mit zylinderförmigem Körper festgestellt. Diese Kompositgeschosse haben einen aus einem Eisenschmiedestück gebildeten Kern, der von einem Bleimantel umgeben ist.

Die übrigen Militaria sind nur durch wenige Funde vertreten. Dabei handelt es sich um Steigbügelfragmente, Parierhaken von Jagdmessern und um einen Sporn (Tab. 4). Als Bestandteil einer Armbrust können zwei Steigbügelfragmente bezeichnet werden (Abb. 10).

Dank den bei der Detektorsuche aufgezeichneten Lagen der einzelnen Metallfunde können wir mit mehr als 260 Punkten arbeiten. Beim Eintragen aller Militaria ohne weitere Klassifizierung bietet sich ein Überlick über die Verteilung der in Bezug zu Rychmberk gemachten Funde. Funde kommen an beiden Hängen des Burghügels vor, auch an beiden gegenüberliegenden Hängen konzentrieren sie sich, und in einer größeren Anzahl ziehen sie sich auch in nördlicher Richtung entlang des Tals des Baches Liberský potok hin. Die meisten Funde befinden sich weniger als $180 \mathrm{~m}$ vom Burgkern entfernt (Abb. 11).

Aufgrund der Fundverteilung können sie mit einem gewissen Unsicherheitsgrad in Militaria unterteilt werden, die gegen die Burg abgefeuert wurden und in solche, die ihren Verteidigern gehörten. Als mit den Angreifern verbundene Funde können in direkter Nähe von Rychmberk gemachte und von den Hängen des Burghügels stammende Artefakte betrachtet werden. Umgekehrt betrachten wir außerhalb des Burgfelssporns (besonders an den gegenüberliegenden Hängen) entdeckte Funde als von den Verteidigern der Burg gegen die Eroberer abgefeuerte Munition. Die meisten entdeckten Funde wurden somit von der Burg gegen die Angreifer abgefeuert. Es überrascht nicht, dass sich die Hauptkonzentration an beiden gegenüberliegenden Hängen befindet, und zwar an den Stellen, die sich dem Burgkern am nächsten befinden (ca. 100-170 m).

Pfeilspitzen kommen als am meisten vertretene Militariagattung in allen Fundkonzentrationen und -lagen vor. Auf den Pfeilschaft mit einem Dorn aufgesetzte Spitzen sind sowohl auf dem Felssporn, als auch in den umliegenden Lagen vertreten und wurden demnach sowohl von den Verteidigern, als auch von den Angreifern verwendet. Dieselbe Situation herrscht auch bei den mit Tüllen versehenen Pfeilspitzen (Abb. 12). Die meisten gefundenen Feuerwaffenprojektile wurden von den Verteidigern abgeschossen. Im Burgareal fanden sich nur fünf zylinderförmige Projektile. 
Im Hinblick auf den Charakter der Kollektion und die geringere chronologische Sensibilität von Militaria können die Funde jedoch keinem konkreten historischen Ereignis zugeordnet werden. In den schriftlichen Quellen sind in den Jahren 1425, 1441 und 1457 Belagerungen der Burg belegt. Beim Blick auf die Karte, auf der die Verteilung der Militaria eingezeichnet ist, registrieren wir mindestens drei erfolgreiche Militäraktionen gegen die Burg. Obwohl wir nicht dazu in der Lage sind, die einzelnen Artekfakte nach den in den schriftlichen Quellen verzeichneten Belagerungen zu differenzieren, kann uns die Fundkonzentration jedoch zumindest eine Tendenz in der Strategie der Angreifer andeuten. Die Lage der Burg ermöglichte es den Eroberern Positionen einzunehmen, von denen sie Rychmberk aus relativ kurzer Entfernung unter Beschuss nehmen konnten. (Abb. 14). Dem entspricht auch die jeweilige Konzentration an Pfeilspitzen und Projektilen am nördlichen und gegenüberliegenden südlichen Hang. Anhand ihres Vorkommens kann einerseits die Anwesenheit von Angreifern an diesen Stellen und das Bestreben der Verteidiger andererseits belegt werden, deren Aktivitäten zu verhindern bzw. eher einzudämmen.

Was die Anzahl der gefundenen Militaria betrifft, die mit der Belagerung der Burg in Verbindung gebracht werden können (besonders Pfeilspitzen, Feuerwaffenprojektile), zählt die Kollektion von Rychmberk im Kontext des mitteleuropäischen Raumes zu den zahlenmäßig größten.

Der vorliegende Beitrag entstand unter Förderung der Spezialforschung der Phil. Fak. Universität Hradec Králové 2021 Zerstörungsfreie Formen der Erforschung mittelalterlicher und neuzeitlicher Befestigungsanlagen.

Mgr. Pavel Drnovský, Ph.D., Katedra archeologie Filozofické fakulty Univerzity Hradec Králové, Rokitanského 62, 50003 Hradec Králové, Česká republika, pavel.drnovsky@uhk.cz

Bc. Tomáš Bek, Archeologický ústav AV ČR, Praha, v. v. i., Letenská 4, 11801 Praha 1, Česká republika, bek@arup.cas.cz

PhDr. Martina Beková, Muzeum a galerie Orlických hor, Jiráskova 2, 51601 Rychnov nad Kněžnou, Česká republika,bekova@moh.cz 
